MERGER ABNORMAL RETURNS AND PAYMENT

METHODS OF HOSPITALITY FIRMS

\author{
By \\ JING YANG \\ Master of Science in Hospitality Administration \\ Oklahoma State University \\ Stillwater, Oklahoma \\ 2008
}

Submitted to the Faculty of the

Graduate College of the

Oklahoma State University

in partial fulfillment of the requirements for

the Degree of

MASTER OF SCIENCE

May, 2008 


\section{MERGER ABNORMAL RETURNS AND PAYMENT METHODS OF HOSPITALITY FIRMS}

Thesis Approved:

\begin{tabular}{c} 
Hailin Qu \\
Thesis Adviser \\
Richard F. Ghiselli \\
\hline Jerrold Leong \\
\hline
\end{tabular}

A. Gordon Emslie

Dean of the Graduate College 


\section{TABLE OF CONTENTS}

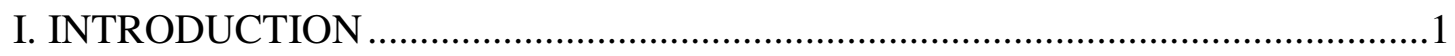

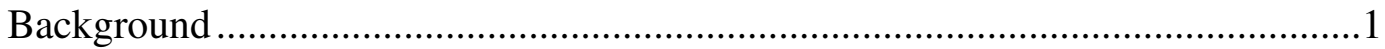

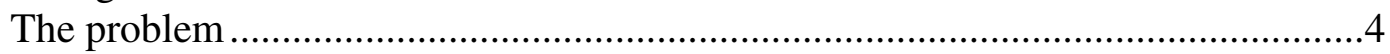

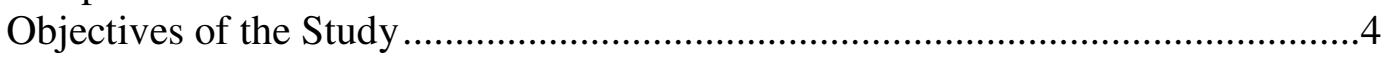

Significance of the Study ...............................................................................

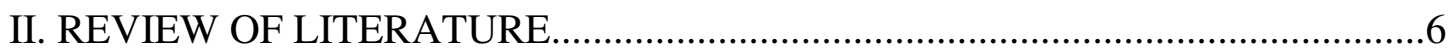

Applied Models.................................................................................................6

Modern Portfolio Theory and Cumulative Average Residuals............................6

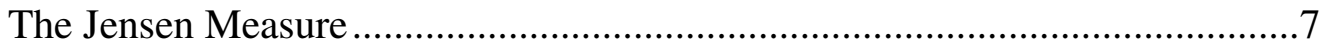

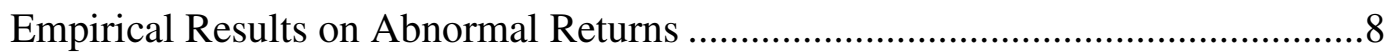

Theories of Payment Methods .............................................................................

Payment Signaling Theory …………………………................................11

Overpayment Theory .............................................................................

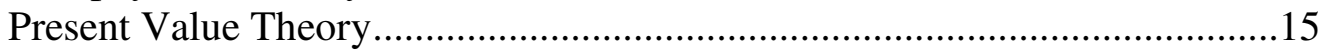

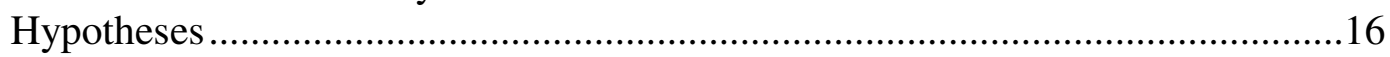

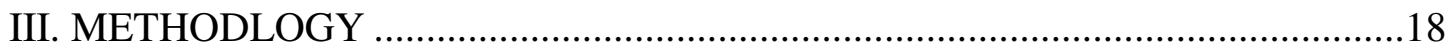

Data

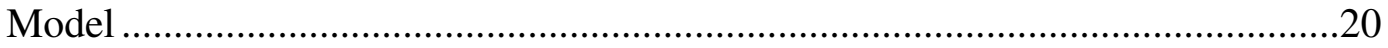

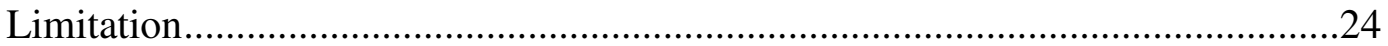

IV. FINDINGS

Long Term Performance of Hospitality Acquirers ………………….....................26

Long Term Performance of Individual Hospitality Acquirers...........................26

Long Term Performance of Sub-group Hospitality Acquirers ..........................28

Payment Methods and Abnormal Return..............................................................29

The Impact of Payment methods and Merger Size on Percentage Excess Return.........................................................................29

The Three Months Results .................................................................. 30 


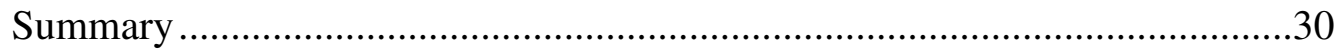

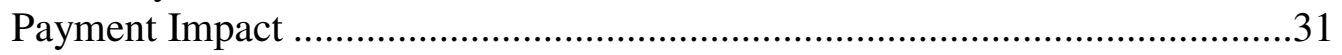

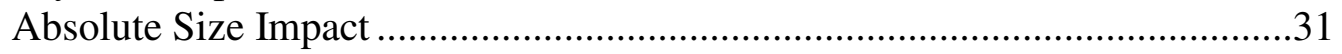

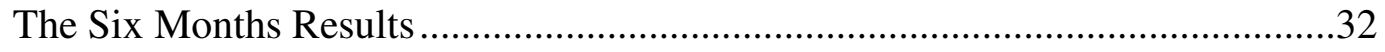

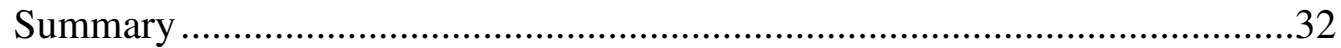

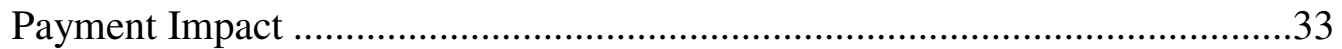

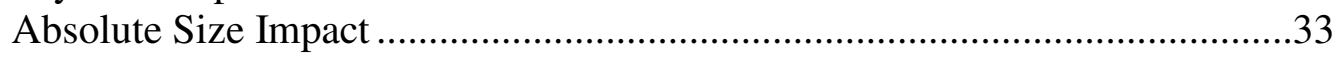

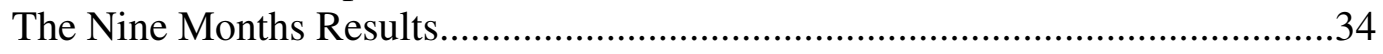

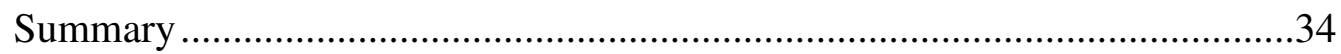

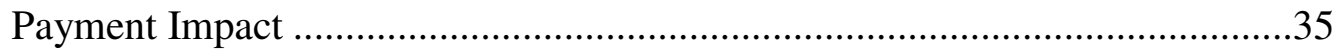

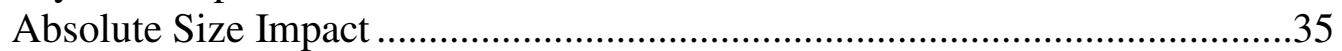

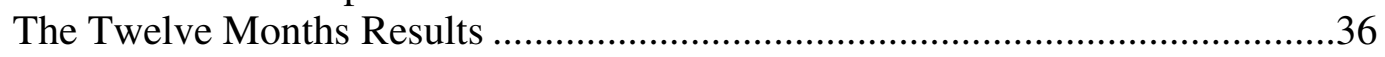

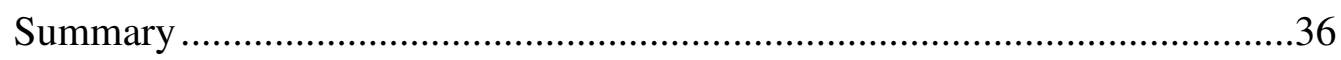

Overall Trend of the Impact on Percentage Excess Return ................................36

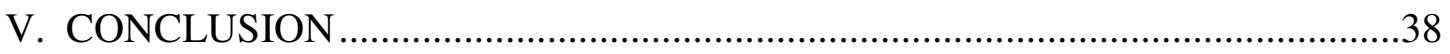

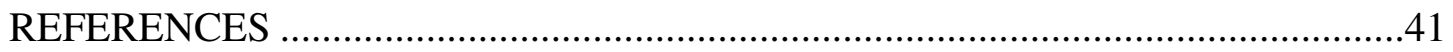

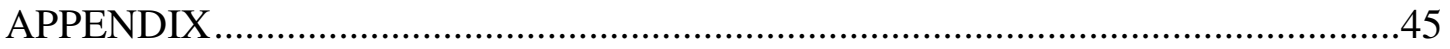

APPENDIX 1-STUDIED MERGER LIST AND MERGER VALUE............45 APPENDIX 2-ACQUIRER'S HISTORICAL STOCK PRICE, STOCK RETURN, STOCK EXCESS RETURN, MARKET INCIDICES RETURN, AND MAKRET INDICES EXCESS RETURN .......................................46-64 APPENDIX 3-LODGING INDUSTRY MERGER AND ACQUISTION TREND

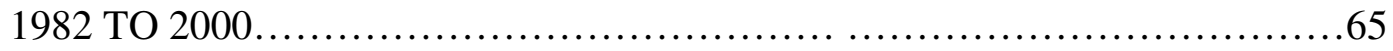
APPENDIX 4-INDICES COMPARISON 1999 TO 2007..................66-68 


\section{LIST OF TABLES}

$\begin{array}{lll}\text { Table } & \text { Page }\end{array}$

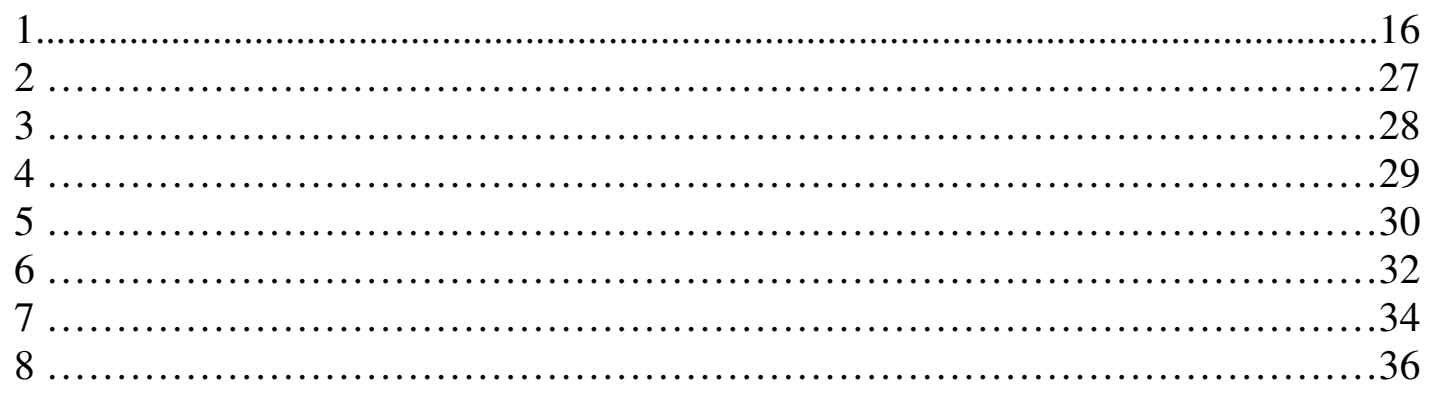

LIST OF FIGURES

$\begin{array}{ll}\text { Figure } & \text { Page }\end{array}$

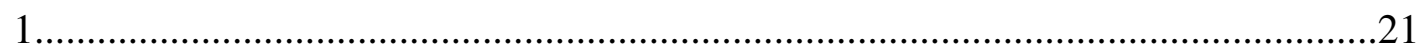




\section{CHAPTER I}

\section{INTRODUCTION}

\section{Background}

Merger and acquisition have been an effective asset development strategy for corporate America since the early 1900s. Historically, four major waves of such activities have contributed to the U.S. economic infrastructure and corporate development changes. The involved industries have shifted from heavy manufacturing and mining areas to the more service driven sectors. Accordingly, activity themes have also evolved throughout the four waves.

Merging for monopoly is the feature of the first wave (prior to 1900). Major producers in numerous industries began horizontal integrations in search of market dominance. The following market crash led to the creation of Federal Trade Commission. The second wave started in 1920 and peaked in 1928. Merging for oligopoly, one third of the activities occurred in the banking and public utility sectors during the nine years. The epitome of the third wave (mid 1950's and peaked in 1967-1969) was merging for growth and synergy. Acquired firms included small- to medium-sized firms in fragmented markets. The strategy of corporate diversification into new product markets became popular. Started in 1975 and ended by 1991, the fourth wave heavily involved 
service industries, such as sectors of finance and bank. It's interesting to note that the service-oriented industries accounted for over $30 \%$ of all mergers and acquisitions in that period. Later in the 1990s, hostile takeovers became a common scene. Most activities were increasingly becoming corporate divestures as companies swapped assets and started to search for better portfolios of business (Gilson, Meyers, Stern, and Black, 1995).

The twenty first century unfolds with some ups and downs in the levels of merger and acquisition activities. The sluggish developments in 2001 and 2002 were later reversed by the surge of financial sponsors and CEO's confidence in strategic acquisitions since 2003. The robust increase continued to 2006. More and more merger and acquisition activities have become an effective corporate strategy to supplement international growth and "soul searching" for core business. During 2005, the Americas accounted for $48 \%$ of global merger and acquisition activities with the total dollar volume of 1,298. 8 billion (Barshay and Falk, 2006).

With the fast growth of domestic and international economy in the last several years, the hotel industry has enjoyed steady improvement in its operating revenues and profit margin, resulting in strong stock performance. The ascent in real estate values has also attracted a broad range of investors who are interested in the underlying assets of hotel companies. Consequently, the combination of unprecedented appreciation in hotel assets and strong cash flows has led to an abundance of consolidation in the hospitality industry, and most recently, a number of leveraged buy-out transactions such as Fairmont Hotel and Four Seasons (Yang and Kim, 2007). The industry today appears much less fragmented. The trend of consolidation is likely to continue in the foreseeable future (Hsu 
and Jang, 2006).

Canina (2001) estimated that from 1982 through 2000, the lodging industry had 57 acquisitions with total market value in the target company's stock over $\$ 53$ billion. The increase in the total market value is 1,000 times greater from 1993 to 1998 for public and private mergers combined. Public lodging companies took a leading role in the activities. In comparison, these companies had 25 more transactions with a total of \$ 44,354.4 million over the private lodging companies. The specifics in both the private and public lodging industry acquisitions were illustrated in Appendix one. The Hotel and Real Estate Investment Trust (REITs) sectors have also experienced profound transformation in recent years. One of the major developments has been consolidation at various scales and levels (Yang and Kim, 2007). Overall, the last two decades of the twentieth century witnessed a record growth of merger and acquisition in the hospitality industry that peaked in the late 1990s.

Accompanied by asset exchange is the payment change in the transaction. In the 1960's, common stock or equivalents such as convertible debt, convertible preferred, or debt plus warrants were dominant; while in the mid 70's, cash replaced equity to become the principal payment method in the transaction. In 2005, $60 \%$ of global merger and acquisition activities were entirely cash transactions, as compared to lows of $27-28 \%$ in the three years from 1998 to 2000 (Barshay and Falk, 2006). The combination of cash and stock remains a common form of payment even though less popular. It represents $28 \%$ of global merger and acquisition activities in 2005, down from the high of $48 \%$ in 2001 (Barshay and Falk, 2006). 
In principle, significant forces in payment selection include marginal tax rates, the magnitude of capital gains, the strength of the economy, and the stock itself (Gilson, Meyers, Stern, and Black, 1995). Historically, the relationship between the premiums paid in a successful acquisition and the acquirers' stock prices over time is negative. In other words, the higher the premiums paid to the target company, the weaker the stock performance of the acquiring company in the long run. Some empirical research shows that the issuance of equity has been flagged as a negative sign in the market and is often trailed with reduction in the firm value (Slovin, Sushka, and Polonchek, 2005).

\section{The Problem}

A well-accepted perception in the literature of merger and acquisition is that target firms receive larger gains in the activity compared to the acquiring firms surrounding the announcement of the event (Gilson, Meyers, Stern, and Black, 1995). Yet previous empirical studies found controversial results on the abnormal returns to the acquirers (Dodd and Ruback, 1977; Asquith, Bruner, and Mullins, Jr., 1983; Canina, 2001; Dodd, 1980; Asquith, 1983; Sheel and Nagpal, 2000; Hsu and Jang, 2006; and Yang and Kim, 2007); limited attention has attributed to the abnormal returns and the effect of different transaction media on the gains to the acquirers in the long term.

\section{Objectives of the Study}

This study aims to examine the long-term returns and the association with payment methods in the context of the U.S. hospitality acquiring firms. More specifically, this study has the following three objectives:

1. Examine long term returns of hospitality acquiring firms; 
2. Explore the differences on long term returns to the hospitality acquiring firms between cash payment and equity payment; and,

3. Evaluate the relationship between returns and payment methods with regard to relative and absolute merger size over time.

\section{Significance of the Study}

Previous studies have contributed to the understanding of abnormal returns of acquiring companies in the short term. S \& P 500 market index is assigned as market benchmark. In the study, hospitality indices are applied to offer a more industry relevant explanation for merger effect. Studies of payment methods in merger and acquisition activities are also limited in the hospitality industry. The result of the study is beneficial to hospitality executives in decisions of whether to initiate merger deals and which means to complete transactions. 


\section{CHAPTER II}

\section{REVIEW OF LITERATURE}

The Federal Trade Commission (FTC) classifies a merger into three categories: horizontal, vertical, product and market concentric or conglomerate categories. Previous literature emphasized the fundamental understanding of synergy. Synergy is created when two companies are better off together than apart (Lubatkin, 1983).

The universally acknowledged rule for mergers suggests that as long as the prospective returns of the combining enterprises are not perfectly correlated, the surviving firm will yield an income stream for its owners having less dispersion per dollar of expected return than would be attainable by holding only one of its predecessors. On the other hand, to claim that the market will pay premium for the new income stream ignores the opportunity which individual investors had prior to the merger to combine the

predecessor shares in their own portfolios (Michel and Shaked, 1985, p.109).

\section{Applied Models}

\section{$\underline{\text { Modern Portfolio Theory \& Cumulative Average Residuals }}$}

Intuitively, acquiring firms benefit from merger due to technical, pecuniary, and diversification synergies. However, empirical studies of various industries, especially the financial industry using the capital asset pricing model, report gains mainly to the shareholders of the acquired firms (Lubatkin, 1983). 
In general, most studies on the short term returns apply an "event-study" framework, or "residual analysis". Relatively large samples of mergers were required. The return on common stock of both the acquiring and acquired firms prior to the "event" date was studied. Event date is a reference date from which analysis is made. The procedure begins with an adjustment of the stock risk by using Modern Portfolio Theory (MPT) to calculate Beta. This theory suggests that the expected return on a security is the sum of risk free rate of interest using Treasury Bill rate and a risk premium (Michel and Shaked, 1985). Abnormal residual occurs when there is a difference between the actual return and the predicted return by MPT. For each firm in the sample, daily residuals are averaged, and for each day, the residuals are averaged for all firms in the sample.

Cumulative average residuals (or CARs) is applied by cumulating these average residuals over a period of time to study the impact of the merger on the shareholders' wealth. Michel and Shaked's survey (1985) indicated that stockholders of target firms earned abnormal gains from the mergers while acquiring firms gained less significant returns than comparable non-acquisitive companies or the average of the acquiring firms' home-base industries. MPT and CARs models are commonly used for measuring shortterm returns, in other words, market reaction to merger announcement.

\section{The Jensen Measure}

Previous literature (Frank, 1991; Sheel \& Nagpal, 2000; Hsu and Jang, 2006;

Yang and Kim, 2007) suggested that the Jensen Measure (Jensen, 1968), expressed as the intercept of the regression of the excess return of the acquiring firms on the excess return of the market index, offers a reasonable measure of merger performance for acquirers in the long term. 
The Jensen Measure of the portfolio $\mathrm{p}\left(\alpha_{\mathrm{p}, \mathrm{t}}\right)$, the excess return for company $\mathrm{p}$, and the excess return of the market portfolio were expressed using the equation (1) (Jensen, 1968).

$$
\left(R_{p, t}-R_{f, t}\right)=\alpha_{p, t}+\beta_{p, t}\left(R_{m, t}-R_{f, t}\right)+\varepsilon_{p, t}
$$

Where,

$\mathrm{R}_{\mathrm{p}, \mathrm{t}}=$ shareholder return for acquirer $\mathrm{p}$ in month $\mathrm{t}$, which is the spread of the return on month $\mathrm{t}$ and $\mathrm{t}-1$ divided by the return on month $\mathrm{t}-1$,

$\mathrm{R}_{\mathrm{f}, \mathrm{t}}=$ monthly U.S. Treasury Bills, which is $1 / 12^{\mathrm{th}}$ of the yearly yield, $R_{p, t}-R_{f, t}=$ the excess return for company $p$ in month $t$, $\alpha_{\mathrm{p}, \mathrm{t}}=$ the Jensen Index of company $\mathrm{p}$ measuring abnormal performance, $\beta_{p, t}=$ volatility coefficient of company $p$ to the S \& P 500 index,

$\mathrm{R}_{\mathrm{m}, \mathrm{t}}=$ return on market index in month $\mathrm{t}$, which is expressed as the spread of the $\mathrm{S} \& \mathrm{P}$ 500 index return on month $\mathrm{t}$ and $\mathrm{t}-1$ divided by the return on month $\mathrm{t}-1$, $R_{m, t}-R_{f, t}=$ the excess return for the $S \&$ P 500 market portfolio, $\mathrm{t}=$ month relative to the announcement date $(\mathrm{t}=0$ is the announcement month), $\varepsilon_{\mathrm{p}, \mathrm{t}}=\mathrm{a}$ random and serially independent error with mean zero.

\section{Empirical Results on Abnormal Returns}

Industry-specific empirical research shared some commonalities (Dodd and Ruback, 1977; Asquith, Bruner, and Mullins, Jr., 1983; Canina, 2001) while others indicated opposite results (Dodd, 1980; Asquith, 1983; Sheel and Nagpal, 2000; Hsu and Jang, 2006). It is noticeable these studies differ in the sample time periods, definitions of event date, models used to generate abnormal returns, time frames prior to and post merger, payment methods, merger sizes, and merger types. 
Dodd and Ruback (1977) studied a sample of 172 bidding firms and 172 target firms to analyze market reaction to both successful and unsuccessful tender offers. The results indicated that target firm stockholders gained positive and significant abnormal returns of $20.58 \%$ for successful offers and $18.96 \%$ for unsuccessful offers. The stockholders of the acquiring firms also earned positive abnormal gains in the month of announcement but their gains were smaller compared to that of the target firms.

Dodd (1980) continued to study a comprehensive sample of the public announcement of proposals to acquire. In total, the author studied 151 merger proposals during 1971 to 1977 . The study showed that there was a swift and positive reaction to the approval of completed proposals and a negative reaction to cancelled proposals. For the stockholders of the target firms, they generally earned large positive abnormal returns from the announcement of the proposals, regardless of the completion of the proposal. For the shareholders of the bidder firms, a negative abnormal return of -7.22 to $-5.50 \%$ was reported.

Asquith (1983) studied stock returns for the entire merger process for both successful and unsuccessful merger bids. The author suggested that target firms created synergy by providing unique resources; however the shareholders of the acquiring firms gained insignificant benefit from the merger, if any. Asquith, Bruner, and Mullins, Jr. (1983) focused exclusively on the gains for the stockholders of the acquiring firms. To test the hypothesis of whether shareholders of bidding firms benefit from mergers, the study examined bidding firms for period 1955-1979. Their research showed significant gains to the acquiring firms during the twenty-one days prior to the announcement of bids. Franks, Harris, and Titman (1991) studied the postmerger performance while 
others (Dodd, 1980; Asquith, Bruner, and Mullins, Jr., 1983) focused on the effect of the announcement gains. The authors examined share-price performance of post 399 corporate takeovers during 1975-1984 using multifactor benchmarks (Lehmann and Modest, 1987; Grinblatt and Titman, 1988 and 1989). They further analyzed the subgroups of the sample to evaluate potential determinants of postmerger performance such as payment in the merger, the relative sizes of the target and the bidder, the level of opposition by incumbent management, and the presence of competing bidders. With cross sectional analysis in event time and portfolio analysis in calendar time, the authors found that different benchmarks generated significantly different measures of postmerger performance.

Canina's research (2001) was among the first endeavors to focus on the merger effect in the hospitality industry. The author found significant positive returns for both the acquired lodging firms and acquiring lodging firms on the merger-announcement day. The author argued that merger and acquisition in the lodging industry involved companies with similar core business; moreover, the senior managers possessed a comparatively larger portion of shares in the equity than in other industries, thus they shared ultimate interest with owners of the business. These characteristics made the merger and acquisition in the lodging industry different from other industries. Hence, it was rational to see that acquisitions in the lodging industry increased equity value for the shareholders.

In contrast to Canina (2001), Hsu and Jang (2006) found out negative returns significant from zero over the long term for hospitality acquiring firms using the Jensen Measure. Yang and Kim (2007) shared some similarities with Hsu and Jang (2006) only 
when industry relevant indices were selected. Yet when selecting the S \& P 500 as market benchmark, the study derived significant positive returns over the long term for hospitality acquiring firms.

In general, it is acknowledged that target firms receive more abnormal returns than the bidding firm. However, the effect of merger on acquiring firms has yet come to a consensus. The inconclusiveness is often resulted from the diverse research focus and directions. One of the most controversial aspects is the effect of payment methods. Extant literature has advised that the methods of payment are important factors for abnormal returns to both bidding and target firms. However, there are limited studies that provide direct correlations between the bidding firms' differential returns and the different methods of payment. In fact, the empirical results are often conflicting (Travlos, 1987).

\section{Theories of Payment methods}

Theoretically, there are three competing theories on payment methods in association with the returns to the bidders: the payment signaling hypothesis, the overpayment hypothesis, and the present value hypothesis (Wansley, Lane, and Yang, 1987).

\section{Payment Signaling Theory}

The extant signaling hypothesis originated from the Myers and Majluf's asymmetric information model (1984). The model suggests that method of payment may provide valuable information to the market. Angelo and others (1984) are among the first who argued that payment method in the merger transaction was a signal of the true value of the bidding firm. 
If the acquiring firm has information concerning its intrinsic value, which is not fully represented in the preacquisition stock price, the management can choose to finance the acquisition in the most beneficial way for its existing shareholders (Tavlos, 1987). Generally, overvalued acquirers have an incentive to offer stock and undervalued acquirers pay with cash. Specifically, if the future market value of outstanding stocks of the acquiring firm is assessed as lower than the current quote, acquirers will choose stock as the media of exchange (Wansley, Lane, and Yang, 1987). Cash financing occurs when acquiring companies has a favorable valuation for its future stock performance. Therefore, the methods of payment may release information of the future prospects of the acquiring company to the market. Stock offerings signal a negative sign.

Empirical studies on the signaling hypothesis are widely tested. On one hand, evidence from a number of researchers (Conn and Nielsen,1977; Bradley, 1980; Asquith, Bruner, and Mullins, 1983; Wansley, Lane, and Yang, 1987; Travlos, 1987; Franks, Harris, and Mayer, 1988;) suggested that cash offers accumulate positive gains for the acquirers and equity offers result in capital loss. On the other hand, a more recent study by Slovin, Sushka, and Polonchek (2005) found stock exchange created significantly larger combined gains shared between the sellers and buyers in inter-corporate asset sales.

Conn and Nielsen (1977) associated negative results with equity exchanges. In the context of L-G model (formal model of premium payment determination for mergers developed by Larson and Gonedes), they found wealth loss both to the acquired and acquiring firms with greater loss to the latter. 
While Conn and Nielsen (1977) showed negative returns to the bidding firms with equity offers, Bradley (1980) suggested positive returns associated with cash offers. The proposed theory of tender offers suggested that the information released from the offer motivates other firms to initiate value-increasing changes in the operations of the target firm. A proportion of the future return from preparing the tender offer becomes available once the formal offer starts. Successful completion of cash offers was a value-increasing activity for both target and bidding firms. On the surface, acquiring firms failed to gain from the appreciation of the target firm shares and suffered a capital loss on the target shares that they purchase. Eventually they benefited from the transaction due to the value-increasing effect of the underlying synergy in the long run. In the study, 161 successful cash offers realized an average of $9 \%$ increase in the market value for the bidding firms on their own shares.

With an attempt to test the three conflicting payment hypotheses, Wansley and others (1987) studied a sample of 199 acquisitions with 64 cash transactions and 118 securities exchanges between 1970 and 1978. Consistent with the payment signaling hypothesis, their results showed a significant positive $6.17 \%$ abnormal gains in the cumulative daily residuals $\left(\mathrm{CAR}_{\mathrm{s}}\right)$ for the bidding firms using cash payment. Meanwhile, their study yielded an insignificant negative $1.51 \%$ with the securities transaction around the announcement of merger.

Travlos (1987) was a pioneer in identifying a direct relation between the different returns and different methods of payments. With a sample of 167 acquiring firms, the study tested the effect of three different payment methods: cash, stock, and combination of the two. The study showed a significant loss on pure stock exchanges and normal rate 
of returns on cash offers for acquirers. And the differences between the two groups are statistically significant and independent of acquisition types.

Contrary to Myers and Majluf's model (1984) and fellow researchers (Conn and Nielsen, 1977; Bradley, 1980; Asquith, Bruner, and Mullins, 1983; Wansley, Lane, and Yang, 1987; Travlos, 1987; Franks, Harris, and Mayer, 1988 ;), Slovin and others (2005) hypothesized that the willingness of the seller to accept equity offers have a bearing on the returns to sellers and buyers. Since equity sales have a common valuation orientation for both parties, both parities would gain from such actions through the increase of the buyers share price. The acceptance automatically exposes the seller to the risk of buyer valuation and its performance prior, thus the gesture signals positive values for the seller and the buyer. Their results showed significant $9.77 \%$ abnormal returns for buyers of equity sales. And in total of 89 sales, $80 \%$ generate positive gains for the buyers. The study challenged the previous widely held view on the negative effect of equity sales.

\section{Overpayment Theory}

The second hypothesis, overpayment hypothesis, argues for smaller gains or losses to the bidding firms with cash offers. The theory suggests that cash offers often pay higher premiums for target companies due to several factors: competition, tax effects, regulatory requirements, and the increasing popularity of cash acquisitions. However, the empirical support for the overpayment theory is inclusive (Gordon and Yagil, 1981; Wansley, Lane, and Yang, 1983; and Sung, 1993).

Theoretically, target companies are more likely to choose cash bidders with higher premiums. From the bidder's side, cash offers are an effective corporate finance strategy to preempt a potential competing bidder. Moreover, shareholders of the target 
companies demand higher premium for cash offers due to capital gains tax. In an equity acquisition, there are no immediate capital gains; therefore, investors are not subjected to capital gains tax liability when they accept stocks of the acquiring company. These taxes are deferred until investors choose to sell and realize the gains. Whereas in the cash acquisition, investors' gains must be realized for tax purposes, thus resulting in a tax liability at the capital gains tax rate (Franks, Harris, and Mayer, 1988).

Wansley, Lane, and Yang (1983) studied 203 acquisitions in the 1970s. The researchers found that target shareholders in cash offers received twice as many returns as shareholders in stock offers. Similar differences in abnormal returns were also recorded by Gordon and Yagil (1981) (Wansley, Lane, and Yang, 1987).

In a comparison study of all competing hypotheses, Sung (1993) focused on the overpayment hypothesis and the effects of overpayment with a sample of 159 cash offers and 63 stock exchange offers during 1974 to 1980. The study found significant negative abnormal returns to the bidders with both cash and stock offers in 1980s and insignificant negative returns in 1970s. This study argued that the overpayment effects were essential to understand the market reaction to takeover bids in the 1980s.

\section{Present Value Theory}

The third hypothesis on payment is the present value theory. It suggests minimal gains to bidding firms, if any, and the gains should not be significantly different from zero. Under an efficient market, the merger releases positive information about the target; other bidders are free to enter the competition. The merger and acquisition activities are argued to be net present value projects for the bidder (Wansley, Lane, and Yang, 1987). 
Arguably a variant of present value theory (Wansley, Lane, and Yang, 1987), the hubris hypothesis suggests that merger activity is a zero net present value project. The gains accumulated to the target company equals to the losses of the bidding firms due to management valuation errors and overpayment. The hubris theory implies that the bidding company experiences wealth losses through merger activities. This theory has yet to be tested empirically. In sum, the differences in the literature on the gains to the bidding firms are summarized in the table below.

Table 1

ABNORNAL GAINS TO BIDDING FIRMS UNDER FOUR CONTENDING HYPOTHESES

\begin{tabular}{|c|c|c|c|c|}
\hline & Signaling & Overpayment & Present Value & Hubris \\
\hline Cash offers & Positive & Negative & Zero & Negative \\
\hline Equity offers & Negative & Positive & Zero & Negative \\
\hline
\end{tabular}

Adapted from Wansley, Lane, and Yang (1987)

\section{Hypotheses}

To test the implications of theories above, this study examines abnormal returns to acquiring firms and the impact of different payment methods in the long term. More specifically, this study aims to examine the following three hypotheses:

\section{Hypothesis 1.}

The acquiring hospitality firms generate abnormal returns significantly different from zero from the merger activities over the long term.

\section{Hypothesis 2}

The acquiring hospitality firms generate significantly different abnormal returns between stock financing and cash financing over the long term.

Hypothesis 3. 
The long term returns to the shareholders of the acquiring hospitality firms are significantly associated with payment of financing.

Another important factor related to payment methods is the size of target and acquiring firms. It is suggested that the larger the merger size, the larger and more positive the acquiring firm's return. Both the relative size and the absolute size of merger were argued to have important effect on merger returns of bidding firm (Asquith, Bruner, and Mullins, 1983 and 1986). In order to test the effect of size and the interaction of size and form of financing, the following hypotheses are proposed:

Hypothesis $3 a$.

The long term returns to the shareholders of the acquiring hospitality firms are significantly associated with payment of financing under relative size control.

Hypothesis $3 b$.

The long term returns to the shareholders of the acquiring hospitality firms are significantly associated with payment of financing under absolute size control. 


\section{CHAPTER III}

\section{METHODOLOGY}

\section{Data}

A company's financial success can be measured by many parameters; however, the stock performance of a public company remains the most important and often the most objective barometer. For a company that has gone through a merger and acquisition, the financial benefit often takes an extended period of time to become apparent, as the change in management and integration of businesses is often accomplished over time. The transformation adjustment is often highly dependent on the scale and nature of the merging companies' business (Yang and Kim, 2007).

In practice, it is difficult to separate the pure impact of a merger from any shift in the general business environment. This is particularly common for lodging companies and REITS, since their business cycles are highly correlated with the general health of the economy and the economic cycle. Therefore, it is important to study beyond the performance of the acquiring companies themselves. Their performance should be measured against their respective industry sectors (Yang and Kim, 2007).

All hospitality acquirers which completed merger deals between 1996 and 2007 were queried from the database of Bloomberg. There was a proliferation of merger and 
divesture activities during this period in which the U.S. economy went through the volatile technology boom and bust of the early 90s. Bloomberg database is provided through Bloomberg Terminal, a core product of Bloomberg L.P., a leading financial news and data company. Founded in 1981 by Michael Bloomberg, Bloomberg database provides financial software tools, such as analytics, data services, and news, to financial companies and organizations around the world (www.bloomberg.com).

Two sector indices were extracted from the database, Bloomberg US Lodging index and Bloomberg REIT Hotels Index. Bloomberg US Lodging index is a capitalization-weighted index of 16 leading US lodging stocks. Bloomberg REIT Hotels Index is a capitalization weighted index of leading REIT companies with at least $75 \%$ of assets invested in hotel properties (www.bloomberg.com). In the study, monthly data of stock returns, T-bill yields, and sector indices were extracted from Bloomberg beginning the month after the merger and acquisition announcement date. Market values one day after the announcement day for both acquiring and target firms were collected across all sample. Absolute merger size is the actual merger announcement total value in dollars and relative merger size is the absolute mergers size divided by the total value of acquiring firms at the time (Asquith, Bruner, and Mullins, 1990).

The data filtering process took the following steps. First, all hospitality-related mergers and acquisitions between January 1996 and March 2007 in the United States were queried from the database. There were 229 completed deals with 67 billion dollars in total announced acquisition value.

The financing forms for these mergers included cash, stock, debt, and any combination of the three forms. This study examined the separate effect of cash and 
equity financing only. Some acquiring firms kept the payment information and merger total value confidential. These data points were eliminated.

A number of acquirers made multiple acquisitions in the period of interest. To isolate the correlation from each merger, the study adopted the following criteria : 1) if the acquirer made multiple mergers within the same 12 month period, only the largest size deals (in announced acquisition value) were kept; 2) if multiple deals had comparable sizes in less than 12 month period, only the most recent deal was kept; 3) if a company made multiple acquisitions separated by over 12 month in time, the authors kept both deals, effectively treating each transaction as independent data point. Only public hospitality acquirers traded on the New York Stock Exchange (NYSE), American Stock Exchange (AMEX), and National Association of Security Automated Quotations (NASDAQ) were included. Further comparisons against SIC code by Ward's Business Directory confirmed the selected merger deals were hospitality firms, whose SIC codes are either 7011 for hotel and motel or 6798/6799 for REITs. The filtering process led to a final sample of 19 U.S. hospitality acquirers with 9 stock offers and 10 cash offers; the 19 acquirers included 11 lodging and 8 REITs.

\section{Model}

The study used secondary data. The objective was to develop a better understanding of returns and the effect of payment methods on returns of hospitality acquirers in the long run.

In a previous study (Hsu and Jang, 2006), the S\&P 500 Index was selected as the benchmark portfolio. Yang and Kim (2007) found that different abnormal returns were indicated using different benchmarks; and industry indices offered a more accurate 
measurement of excess returns in the long term. More specifically, positive and significant abnormal returns were indicated for shareholders of lodging mergers when the S \& P 500 was selected as the benchmark; shareholders of the REITs mergers received positive gains when compared with the S \& P 500; yet both lodging and REITs acquirers' abnormal returns decreased when the industry indices were selected as the benchmark.

Further comparison of the S \& P 500 index with the sector indices indicated that the hospitality sectors clearly outperformed the general market in the past eight years (from 1999 to 2007) as shown in Exhibit 1. Bloomberg Lodging index and Bloomberg REITs hotel index were applied as sector indices. In addition, lodging sector outperformed the REITs companies. The S \& P 500, Lodging, and REITs indices were converted to facilitate comparison. From the figure below, it follows that hospitality industry as a whole outperformed the overall market in the period of interest.

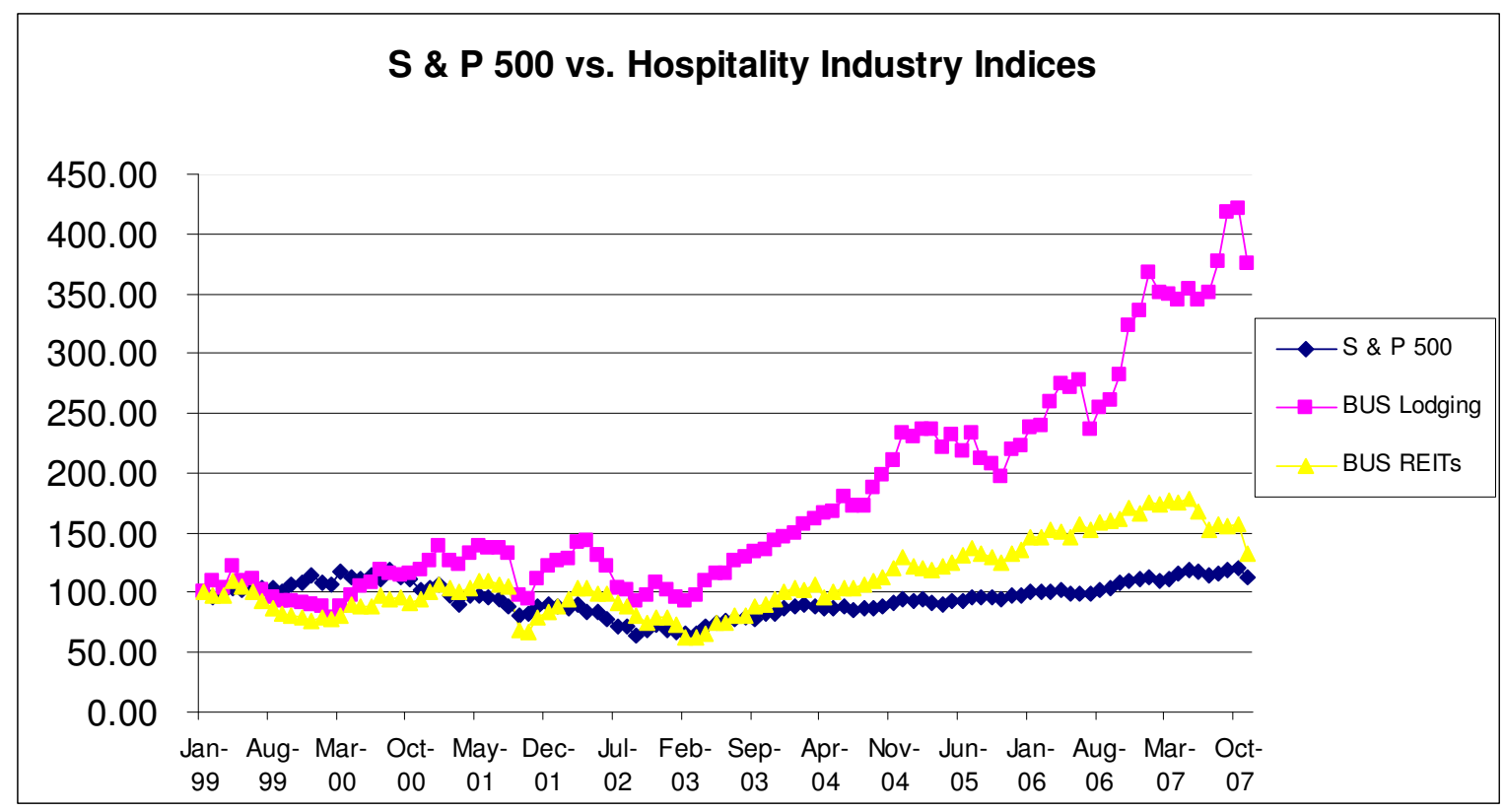

Figure 1. The S \& P 500 Index vs. Bloomberg REITS and Lodging Index 
Consistent with the previous study (Yang and Kim, 2007), the study incorporated both Lodging and REITs hotel indices in the equation (2) for the modified Jensen Measure. Lodging index and REITs index are applied for each subgroup.

$$
\left(R_{p, t}-R_{f, t}\right)=\alpha_{p, t}^{\prime}+\beta_{p, t}^{\prime}\left(R_{m, t}^{\prime}-R_{f, t}\right)+\varepsilon_{p, t}^{\prime}
$$

where,

$\mathrm{R}_{\mathrm{p}, \mathrm{t}}=$ shareholder return for acquirer $\mathrm{p}$ in month $\mathrm{t}$, which is the spread of the return on month $\mathrm{t}$ and $\mathrm{t}-1$ divided by the return on month $\mathrm{t}-1$,

$\mathrm{R}_{\mathrm{f}, \mathrm{t}}=$ monthly U.S. Treasury Bills, which is $1 / 12^{\text {th }}$ of the yearly yield, $\mathrm{R}_{\mathrm{p}, \mathrm{t}}-\mathrm{R}_{\mathrm{f}, \mathrm{t}}=$ the excess return for company $\mathrm{p}$ in month $\mathrm{t}$, $\alpha_{\mathrm{p}, \mathrm{t}}^{\prime}=$ the modified Jensen Index of company $\mathrm{p}$ measuring long term abnormal returns, $\beta_{p, t}^{\prime}=$ volatility coefficient of company $p$ to the lodging/REITs index, $\mathrm{R}_{\mathrm{m}, \mathrm{t}}=$ return on market index in month $\mathrm{t}$, which is expressed as the spread of the sector index return on month $\mathrm{t}$ and $\mathrm{t}-1$ divided by the return on month $\mathrm{t}-1$, $R^{\prime}{ }_{m, t}-R_{f, t}=$ the excess return for the sector portfolio, $\mathrm{t}=$ month relative to the announcement date $(\mathrm{t}=0$ is the announcement month), $\varepsilon_{\mathrm{p}, \mathrm{t}}^{\prime}=\mathrm{a}$ random and serially independent error with mean zero.

First, the data were grouped into two sectors of lodging and REITs. Each lodging and REITs group had one pooled $\alpha^{\prime}{ }_{\mathrm{p}, \mathrm{t}}$ measuring abnormal returns in the long term. Lodging and REITs groups were compared. The study then pooled $\alpha^{\prime} \mathrm{p}, \mathrm{t}$ from both groups. The pooled $\alpha^{\prime} \mathrm{p}, \mathrm{t}$ and its $\mathrm{p}$ value helped to test hypothesis 1 in equation (2).

Secondly, the data broke into two groups based on payment methods. One represented cash offers and the other stock offers. Abnormal returns of each group were 
calculated independently with equation (2). Independent T-test was applied to study the differences on the abnormal return of cash offers and stock offers to test hypothesis 2.

Thirdly, regression analysis was used to test the association of the effect of merger size and the form of financing on the excess returns of the acquiring firms. The study modified the regression model proposed by Asquith, Bruner, and Mullins (1990) to test the power of association in equation (3). Acquirers' stock percentage excess returns on three, six, nine, and twelve months were cross-sectionally regressed against the form of financing with relative size control. The dummy variable was used to differentiate forms of payment testing hypothesis 3 a in equation (3) with $0-1$ coding conversion.

$$
\left(R_{p, t}-R_{f, t}\right)=\beta_{0}+\beta_{1} \operatorname{Size}_{p}+\beta_{2} D+\varepsilon
$$

where,

$R_{p, t}-R_{f, t}=$ the percentage excess return for company $p$ in month $t$,

$\beta_{0}=$ the coefficient of intercept,

$\beta_{1,} \beta_{2}=$ regression coefficients,

Size $_{\mathrm{p}}=$ the relative merger size of the target firm $\mathrm{p}$, i.e. the announced merger value divided by the equity value of the acquiring firm,

$\mathrm{D}=$ the dummy variable that takes the value of 1 if cash is the only announced financing and 0 if common stock is the only announced financing, $\varepsilon=$ a random and serially independent error with mean zero.

The absolute size of the merger was also studied in equation (4).

$$
\left(\mathrm{R}_{\mathrm{p}, \mathrm{t}}-\mathrm{R}_{\mathrm{f}, \mathrm{t}}\right)=\beta_{0}^{\prime}+\beta_{1}^{\prime} \operatorname{Merval}_{\mathrm{p}}+\beta_{2}^{\prime} \mathrm{D}+\varepsilon{ }^{\prime}
$$

where,

$R_{p, t}-R_{f, t}=$ the percentage excess return for company $p$ in month $t$, 
$\beta_{0}^{\prime}=$ the coefficient of intercept,

$\beta_{1,}^{\prime} \beta_{2}^{\prime}=$ regression coefficients,

Merval $_{\mathrm{p}}=$ the announced value of merger,

$\mathrm{D}=$ the dummy variable that takes the value of 1 if cash is the only announced financing and 0 if common stock is the only announced financing,

$\varepsilon=$ a random and serially independent error with mean zero.

\section{Limitation}

The study has several limitations. First of all, the study collected data from 1996 to 2007. The early part of the study period was during a time of significant overall market performance. The hotel sector, in particular, has very positive cash flows and profit margin. Therefore, the concern of generalization remains an issue.

Second, the study has small data points of 19 completed merger deals. Hotel and REITs companies are mostly cash intensive and more prone to select cash transactions. Recent trend of merger transaction also favors cash payment. For mergers that paid with stock and debt, the study treats those as stock offers. Limited number of pure stock offers is another challenge for the study.

Third, the study operationalizes the long term stock return as the percentage excess return. Future studies can convert the percentage returns to dollar-wise returns for better comparison.

Since both Bloomberg REITs and Lodging Index are available only after the mid 1990s, it's challenging to study hospitality merger and acquisitions dated before 1990s with the two indices. Future studies can select other industry relevant indices with an extended period of more than 30 years. With a larger pool of data points, further 
comparisons can be made between combination of payment methods and the single financing methods of either cash or stock on the dollar returns of acquiring companies. 


\section{CHAPTER IV}

\section{FINDINGS}

The Statistical Package for the Social Sciences, Windows Version 14.0 (SPSS 14.0) was used to analyze the data. The purpose of the regression was to test whether hospitality firms receive abnormal gains from merger and acquisition after the activities and the association of payment methods and merger size with the excess return of acquiring firms.

\section{Long Term Performance of Hospitality Acquirers}

\section{$\underline{\text { Long Term Performance of Individual Hospitality Acquirers }}$}

Table 2 indicates the results of the regression on the sector indices for individual hospitality acquirers. In general, there are a total of 19 hospitality companies' data available with 8 in REITs and 11 in lodging, 10 cash offers and 9 stock offers. The Jensen Measures of 9 acquirers are negative and 10 acquirers are positive. For the 11 lodging acquirers, the alphas for 7 acquirers are positive and 4 are negative; for the 8 REITs acquirers, the alphas for 3 acquirers are positive and 5 are negative. For the payment groups, the alphas for 6 cash payment are positive and 4 are negative; for the stock payment, the alpha for 6 acquirers are positive and 3 are negative. Among all studied acquirers, the alphas for four firms are statistically significant. Ameristar Casinos Inc (ASCA), in the lodging group and with cash payment, has gained substantial 
abnormal returns of $15.51 \%$ and its t statistics is 3.89 at .05 level. Harrah's Entertainment Inc (SHO), in the lodging group and with stock payment, has yielded significant negative returns of $-2.37 \%$ and its $t$ statistics is -2.35 at .05 level. MGM Mirage (MGM), in the lodging group and with stock payment, has received significant positive gains of 5.30\% and its $t$ statistics is 2.22 at .05 level. Felcor Lodging Trust Inc (FCH), in the REITs group and with stock payment, has suffered negative loss of $-2.5 \%$ and its t statistics is 1.92 at 0.1 level. The specifics are listed below.

Table 2.

JENSEN MEASURE ANALYSIS OF INDIVIDUAL ACQUIRERS ( $\mathrm{C}=$ cash, $\mathrm{S}=$ Stock, $\mathrm{L}=$ lodging, and $\mathrm{R}=\mathrm{REITs}$ ) $\left(R_{p, t}-R_{f, t}\right)=\alpha_{p, t}^{\prime}+\beta_{p, t}^{\prime}\left(R_{m, t}^{\prime}-R_{f, t}\right)+\varepsilon_{p, t}$

\begin{tabular}{|c|c|c|c|c|c|c|}
\hline Acquirer Name & Payment & Sector & $\alpha_{\mathrm{p}, \mathrm{t}}^{\prime}$ & T-statistics & $\boldsymbol{\beta}_{\mathrm{p}, \mathrm{t}}^{\prime}$ & T-statistics \\
\hline AMERISTAR CASINOS INC (ASCA) & $\mathrm{C}$ & $\mathrm{L}$ & $15.51 \%$ & $3.42 * * *$ & 1.23 & $3.89 * *$ \\
\hline STRATEGIC HOTELS \& RESORTS (BEE) & $\mathrm{C}$ & $\mathrm{R}$ & $0.32 \%$ & 0.24 & 0.61 & 1.84 \\
\hline FELCOR LODGING TRUST INC ( $\underline{\text { FCH}})$ & $\mathrm{C}$ & $\mathrm{R}$ & $-1.80 \%$ & -1.17 & 0.48 & $2.20 *$ \\
\hline HOSPITALITY PROPERTIES TRUST (HPT) & $\mathrm{C}$ & $\mathrm{R}$ & $-0.77 \%$ & -0.80 & 0.79 & $3.08 * *$ \\
\hline LASALLE HOTEL PROPERTIES (능 $)$ & $\mathrm{C}$ & $\mathrm{R}$ & $-0.30 \%$ & -0.2 & 1.31 & $3.03 * *$ \\
\hline LA QUINTA CORP-PAIRED (LQI) & $\mathrm{C}$ & $\mathrm{L}$ & $0.58 \%$ & 0.33 & 0.31 & 1.08 \\
\hline MARRIOTT INTERNATIONAL-CL A (MAR ) & $\mathrm{C}$ & $\mathrm{L}$ & $-0.36 \%$ & -0.37 & 0.56 & $3.48 * * *$ \\
\hline MORGANS HOTEL GROUP CO (MHGC) & $\mathrm{C}$ & $\mathrm{L}$ & $1.60 \%$ & 0.40 & 0.77 & 1.13 \\
\hline OSUNSTONE HOTEL INVESTORS INC (SHO) & $\mathrm{C}$ & $\mathrm{R}$ & $-1.41 \%$ & -1.43 & 0.65 & $2.23 *$ \\
\hline STATION CASINOS INC( $\underline{\text { STN })}$ & $\mathrm{C}$ & $\mathrm{L}$ & $-0.58 \%$ & -0.27 & 0.91 & $3.16^{* *}$ \\
\hline HARRAH'S ENTERTAINMENT INC (HET) & $\mathrm{S}$ & $\mathrm{L}$ & $-2.37 \%$ & $-2.35^{* *}$ & 1.18 & $7.24 * * *$ \\
\hline HILTON HOTELS CORP (HLT) & $\mathrm{S}$ & $\mathrm{L}$ & $-1.84 \%$ & -0.56 & 1.14 & $2.17 *$ \\
\hline HOST HOTELS \& RESORTS INC (HST) & $\mathrm{S}$ & $\mathrm{R}$ & $0.18 \%$ & 0.46 & 1.41 & $11.81 * * *$ \\
\hline PATRIOT AMER HOSPITALITY INC ( $\underline{\text { PAH })}$ & $\mathrm{S}$ & $\mathrm{R}$ & $0.78 \%$ & 0.37 & 1.41 & $4.85 * * *$ \\
\hline MGM MIRAGE (MGM) & $\mathrm{S}$ & $\mathrm{L}$ & $5.30 \%$ & $2.22 *$ & 1.34 & $4.54 * * *$ \\
\hline HARRAH'S ENTERTAINMENT INC (HET) & $\mathrm{S}$ & $\mathrm{L}$ & $3.43 \%$ & 0.95 & 0.53 & 1.12 \\
\hline CAESARS ENTERTAINMENT INC (CZR) & $\mathrm{S}$ & $\mathrm{L}$ & $5.49 \%$ & 1.58 & 1.18 & $2.59 * *$ \\
\hline FELCOR LODGING TRUST INC (FCH) & $\mathrm{S}$ & $\mathrm{R}$ & $-2.50 \%$ & $-1.92 *$ & 0.31 & $1.90^{*}$ \\
\hline BOYD GAMING CORP (BYD ) & $\mathrm{S}$ & $\mathrm{L}$ & $4.11 \%$ & 1.64 & 0.75 & 1.78 \\
\hline
\end{tabular}

Note: $\alpha_{\mathrm{p}, \mathrm{t}}^{\prime}=$ abnormal returns, $\beta^{\prime}=$ volatility coefficient, ${ }^{*} \mathrm{p}<.1,{ }^{*} \mathrm{p}<.05,{ }^{*} * \mathrm{p}<.01$ 


\section{Long Term Performance of Sub-group Hospitality Acquirers}

Further comparisons of sub-groups are listed in Table 3. The alphas of four groups of REITs, Lodging, Cash offers, and Stock offers are pooled. The Jensen Measure of the lodging acquirers is $2.75 \%$ and the t-statistic is 3.0 . The positive alpha and the significant $t$ value suggest that the lodging shareholders receive positive gains in the studied period. The Jensen Measure of the REITs acquirers is $-0.66 \%$ and the t-statistics is -1.31 . The negative alpha and the insignificant $\mathrm{p}$ value suggest that the REITs shareholders underperform lodging acquirers and they fail to receive significant positive gains from merger activities.

The Jensen Measure of cash offer acquirers is $1.28 \%(\mathrm{t}=1.57)$ and that for stock offer acquirers is $1.36 \%(\mathrm{t}=1.64)$. The Jensen Measure of all the pooled data is $1.30 \%$ and the t-statistics is 2.26 . The positive alpha and the significant p-value at .05 level indicate that the studied hospitality acquirers has experienced significant positive equity increases different from zero from 1996-2007. The results support hypothesis 1.

Table 3.

JENSEN MEASURE ANALYSIS OF GROUP ACQUIRERS

$$
\left(\mathrm{R}_{\mathrm{p}, \mathrm{t}}-\mathrm{R}_{\mathrm{f}, \mathrm{t}}\right)=\alpha_{\mathrm{p}, \mathrm{t}}^{\prime}+\beta_{\mathrm{p}, \mathrm{t}}^{\prime}\left(\mathrm{R}_{\mathrm{m}, \mathrm{t}}^{\prime}-\mathrm{R}_{\mathrm{f}, \mathrm{t}}\right)+\varepsilon_{\mathrm{p}, \mathrm{t}}
$$

\begin{tabular}{|c|c|c|c|c|}
\hline & $\boldsymbol{\alpha}_{\mathrm{p}, \mathrm{t}}$ & T-statistics & $\beta^{\prime}{ }_{p, t}$ & T-statistics \\
\hline \multicolumn{5}{|l|}{ Industry Group } \\
\hline Lodging Acquirers & $2.75 \%$ & $3.00 * * *$ & 0.90 & $7.11 * * *$ \\
\hline REITs Acquirers & $-0.66 \%$ & -1.31 & 0.76 & $8.15 * * *$ \\
\hline \multicolumn{5}{|l|}{ Payment Method } \\
\hline Cash Payment & $1.28 \%$ & 1.57 & 0.81 & $6.19 * * *$ \\
\hline Stock Payment & $1.36 \%$ & 1.64 & 0.93 & $7.74 * * *$ \\
\hline All Acquirers & $1.30 \%$ & $2.26 * *$ & 0.87 & $9.89 * * *$ \\
\hline
\end{tabular}

Note: $\alpha_{\mathrm{p}, \mathrm{t}}^{\prime}=$ abnormal returns, $\beta$ ' $=$ volatility coefficient, ${ }^{*} \mathrm{p}<.1,{ }^{*} \mathrm{p}<.05, * * * \mathrm{p}<.01$ 


\section{Payment Methods and Abnormal Return}

Table 4.

T-TEST FOR ABNORMAL RETURNS OF CASH AND STOCK OFFERS

\begin{tabular}{llrccc}
\hline & & & & \\
& PAYMENT & N. & Mean & Std. Deviation & Std. Error Mean \\
\hline \multirow{2}{*}{ ALPHA } & CASH ALPHA & 11 & .012 & .050 & .015 \\
& STOCK ALPHA & 9 & .009 & .034 & .011 \\
\hline
\end{tabular}

In analysis of hypothesis 2, independent T-test is applied between cash offer alphas and stock offer alphas to study whether there are significant differences associated with payment methods. The result is shown in Table 4. The mean of cash offer abnormal return is $1.2 \%$ and for stock offer abnormal return is $0.9 \%$. Statistical difference between the different payment method is $0.003(\mathrm{p}=.862)$. The results are much weaker. The positive and insignificant difference indicates that cash offer and stock offer acquirers do not generate significantly different abnormal returns in the long term. Therefore, hypothesis 2 is not supported. The result differed from Slovin (1987) and Travlos (1987) in which equity financing generated significant different gains from the cash financing.

\section{The Impact of Payment Methods and Merger Size on Percentage Excess Return}

Previous studies found both relative and absolute merger size important indicators for studying merger and acquisition gains and losses (Asquith, Bruner, and Mullins, 1983 and 1986). This study suggests that only absolute merger size has statistical importance. The results of regression analysis of the relation between the dependent variable (long term percentage excess return) and two independent variables (the absolute merger size and payment methods) are reported in Table 5, 6, 7, and 8. The results are grouped in 
three, six, nine, and twelve months post merger. The sectioning aims to study the trend of the impact of the both independent variables on dependent variable in different time frames.

The Three Months Results

Table 5

$$
\begin{aligned}
& \text { THREE MONTHS IMPACT OF PAYMENT METHODS AND } \\
& \text { ABSOLUTE MERGER SIZE } \\
& \left(\mathrm{R}_{\mathrm{p}, \mathrm{t}}-\mathrm{R}_{\mathrm{f}, \mathrm{t}}\right)=\beta_{0}-\beta_{1} \mathrm{Merval}_{\mathrm{p}}-\beta_{2} \mathrm{D}+\varepsilon
\end{aligned}
$$

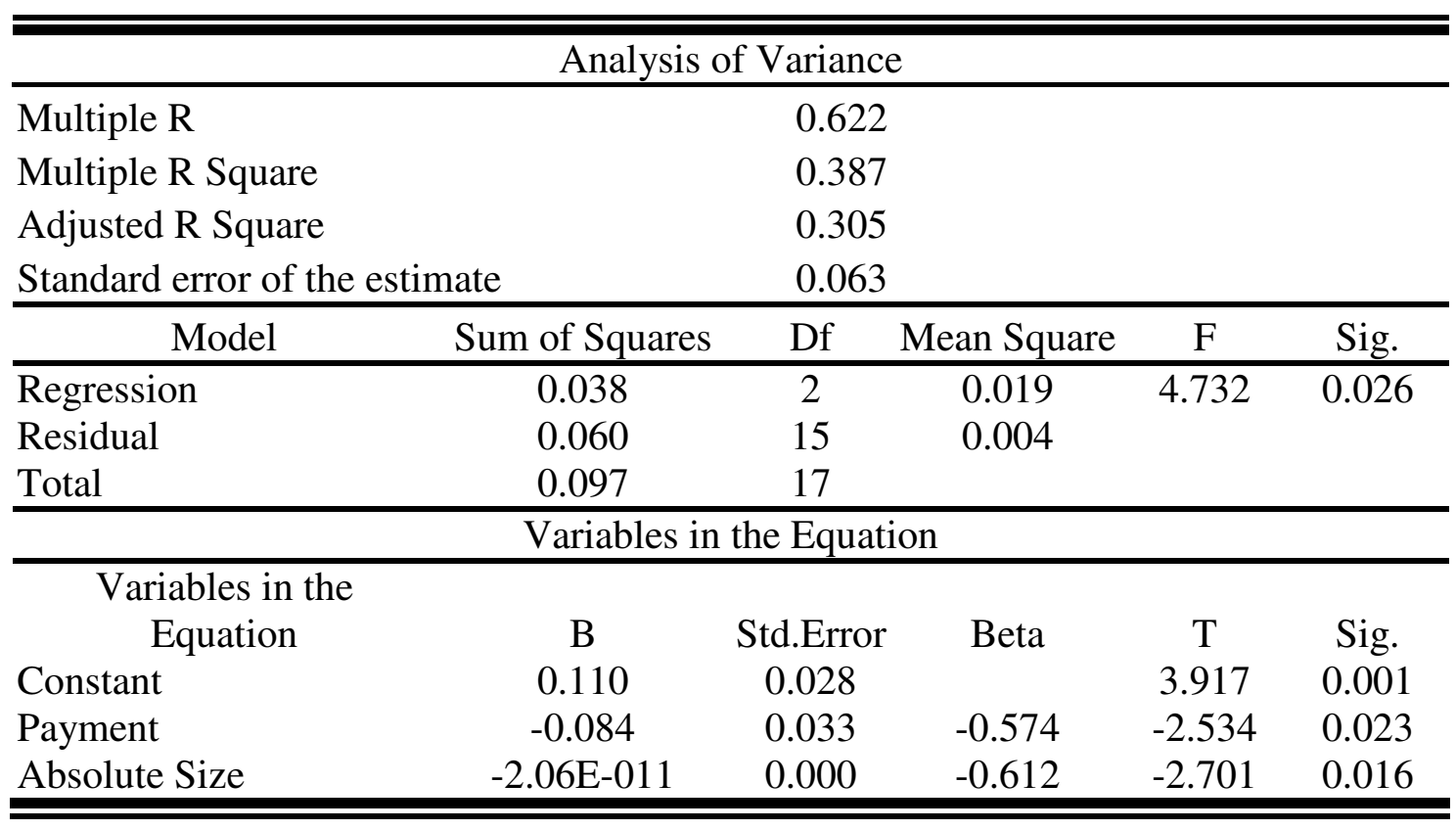

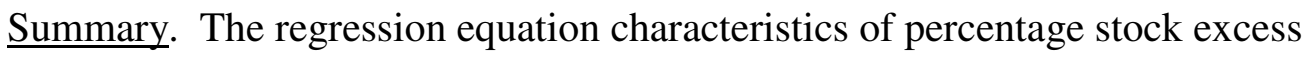
return at three months indicates a reasonable adjusted $\mathrm{R}^{2}$ of 0.30 . It suggests that $30 \%$ of the variation in the percentage excess return is explained by the equation. The F value of 4.732 with significance level less than 0.05 shows that the model is applicable.

The model tests whether two independent variables have significant impact on the dependent variable predicating the performance of acquirers three months post merger. 
Cash payment is coded as 1 and stock as 0 . Both independent variables emerge as significant $(\mathrm{T}<0.05)$ in the model as follows:

where,

$$
\left(R_{p, t}-R_{f, t}\right)=0.11-2.06 E-011 \text { Merval }_{p}-0.084 \mathrm{D}
$$

$\mathrm{R}_{\mathrm{p}, \mathrm{t}}-\mathrm{R}_{\mathrm{f}, \mathrm{t}}=$ the percentage excess return for company $\mathrm{p}$ in month $\mathrm{t}$, Merval $_{\mathrm{p}}=$ the announced value of merger,

$\mathrm{D}=$ the dummy variable that takes the value of 1 if cash is the only announced financing and 0 if common stock is the only announced financing,

The negative sign of cash and absolute size indicate that there is a negative relationship between the two independent variables (cash payment and absolute size) and the percentage excess return for acquirers at three months post merger.

Payment Impact. Cash is coded as 1 and the model shows a negative sign for payment method. The negative coefficient -0.084 projects that merger deals equal in size but financing differently with stock would result in different percentage excess returns. More specially, stock financing would generate $11 \%$ excess returns for acquirers as compared to $2.6 \%$ with cash financing. Ultimately cash financing would cause a loss of $8.4 \%$ of returns three months post merger if the same acquirer opts against stock financing.

Absolute Size Impact. With regard to market equity value, REITs companies vary from 2 to 5 billion, large hotel from 5 to 10 billion, and small hotel are often less than 1 billion. The negative impact of absolute size on the dependent variable percentage of excess return is understandably minimal. 
The negative sign of absolute size indicates a negative relationship between the dependent and independent variable. Yet the impact is comparatively marginal three month post merger.

The Six Months Results

Table 6

SIX MONTHS IMPACT OF PAYMENT METHODS AND

ABSOLUTE MERGER SIZE

$\left(\mathrm{R}_{\mathrm{p}, \mathrm{t}}-\mathrm{R}_{\mathrm{f}, \mathrm{t}}\right)=\beta^{\prime}{ }_{0}-\beta_{1}^{\prime} \operatorname{Merval}_{\mathrm{p}}-\beta_{2}{ }_{2} \mathrm{D}+\varepsilon{ }^{\prime}$

\begin{tabular}{|c|c|c|c|c|c|}
\hline \multicolumn{6}{|c|}{ Analysis of Variance } \\
\hline Multiple R & & 0.606 & & & \\
\hline Multiple R Squar & & 0.367 & & & \\
\hline Adjusted R Squar & & 0.282 & & & \\
\hline Standard error of & nate & 0.028 & & & \\
\hline Model & Sum of Squares & Df & Mean Square & $\mathrm{F}$ & Sig. \\
\hline Regression & 0.007 & 2 & 0.003 & 4.346 & 0.032 \\
\hline Residual & 0.012 & 15 & 0.001 & & \\
\hline Total & 0.019 & 17 & & & \\
\hline \multicolumn{6}{|c|}{ Variables in the Equation } \\
\hline \multicolumn{6}{|c|}{ Variables in the } \\
\hline Equation & B & Std.Error & Beta & $\mathrm{T}$ & Sig. \\
\hline Constant & 0.047 & 0.013 & & 3.754 & 0.002 \\
\hline Payment & -0.043 & 0.015 & -0.660 & -2.865 & 0.012 \\
\hline Absolute Size & $-6.57 \mathrm{E}-012$ & 0.000 & -0.441 & -1.916 & 0.075 \\
\hline
\end{tabular}

$\underline{\text { Summary. The regression equation characteristics of percentage stock excess }}$ return at six months indicates a reasonable adjusted $\mathrm{R}^{2}$ of 0.28 . It suggests that $28 \%$ of the variation in the percentage excess return is explained by the equation. The F value of 4. 346 with significance level less than 0.05 shows that the model is applicable. 
The model tests whether two independent variables have significant impact on the dependent variable predicating the performance of acquirers six months post merger. Both independent variables emerge as significant $(\mathrm{T}<0.1)$ in the model as follows:

where,

$$
\left(R_{p, t}-R_{f, t}\right)=0.047-6.57 E-012 \mathrm{Merval}_{p}-0.043 \mathrm{D}
$$

$R_{p, t}-R_{f, t}=$ the percentage excess return for company $p$ in month $t$, Merval $_{\mathrm{p}}=$ the announced value of merger, $\mathrm{D}=$ the dummy variable that takes the value of 1 if cash is the only announced financing and 0 if common stock is the only announced financing,

The negative sign of both cash and absolute size indicate that there is a negative relationship between the two independent variables (cash payment and absolute size) and the percentage excess return for acquirers at six months post merger.

Payment Impact. Similar to the results three months post merger, the negative coefficient -0.043 predicts that merger deals equal in size but financing differently with stock would result in different percentage excess returns. More specially, stock financing would generate $4.7 \%$ returns for acquirers as compared to $0.4 \%$ with cash financing. Ultimately cash financing would cause a loss of $4.3 \%$ of returns six months post merger if the same acquirer votes against stock financing.

Absolute Size Impact. Compared to three months post merger, the negative impact of absolute size on the dependent variable percentage of excess return is smaller six months post merger. The negative sign of absolute size indicates a negative relationship between the dependent and independent variable. Yet the overall impact of 6.57E-012 is considerably small. 
The Nine Months Results

Table 7

NINE MONTHS IMPACT OF PAYMENT METHODS AND
ABSOLUTE MERGER SIZE
$\left(\mathrm{R}_{\mathrm{p}, \mathrm{t}}-\mathrm{R}_{\mathrm{f}, \mathrm{t}}\right)=\beta_{0}^{\prime}-\beta_{1}{ }_{1} \mathrm{Merval}_{\mathrm{p}}-\boldsymbol{\beta}_{2} \mathrm{D}+\varepsilon$

\begin{tabular}{|c|c|c|c|c|c|}
\hline \multicolumn{6}{|c|}{ Analysis of Variance } \\
\hline Multiple R & & 0.511 & & & \\
\hline Multiple R Squar & & 0.262 & & & \\
\hline Adjusted R Squa & & 0.163 & & & \\
\hline Standard error of & nate & 0.029 & & & \\
\hline Model & Sum of Squares & Df & Mean Square & $\mathrm{F}$ & Sig. \\
\hline Regression & 0.005 & 2 & 0.002 & 2.657 & 0.10 \\
\hline Residual & 0.013 & 15 & 0.001 & & \\
\hline Total & 0.017 & 17 & & & \\
\hline \multicolumn{6}{|c|}{ Variables in the Equation } \\
\hline \multicolumn{6}{|c|}{ Variables in the } \\
\hline Equation & B & Std.Error & Beta & $\mathrm{T}$ & Sig. \\
\hline Constant & 0.044 & 0.013 & & 3.403 & 0.004 \\
\hline Payment & -0.035 & 0.015 & -0.569 & -2.289 & 0.037 \\
\hline Absolute Size & $-4.50 \mathrm{E}-011$ & 0.000 & -0.317 & -1.275 & 0.222 \\
\hline
\end{tabular}

$\underline{\text { Summary. The regression equation characteristics of percentage stock excess }}$ return at nine months indicates adjusted $\mathrm{R}^{2}$ of 0.16 . It suggests that $16 \%$ of the variation in the percentage excess return is explained by the equation. The F value of 2.7 with significance level at 0.1 shows that the model is applicable.

The model tests whether two independent variables have significant impact on the dependent variable predicating the performance of acquirers nine months post merger. Payment is found to be significantly $(\mathrm{T}<0.05)$ related with excess return. The model writes as follows:

where,

$$
\left(R_{p, t}-R_{f, t}\right)=0.044-0.035 D
$$


$R_{p, t}-R_{f, t}=$ the percentage excess return for company $p$ in month $t$,

$\mathrm{D}=$ the dummy variable that takes the value of 1 if cash is the only announced financing and 0 if common stock is the only announced financing,

The negative sign of cash indicates that there is a negative relationship between cash payment and the percentage excess return for acquirers at nine months post merger.

Payment Impact. Consistent with three and six months post merger, the negative coefficient (-0.035) projects that merger deals equal in size but financing differently with stock would result in different percentage excess returns. More specially, stock financing would generate $4.4 \%$ returns for acquirers as compared to $0.9 \%$ with cash financing. Ultimately cash financing would cause a loss of $3.5 \%$ of returns nine months post merger if the same acquirer opts against stock financing.

Absolute Size Impact. The negative sign of absolute size indicates a negative relationship between the dependent and independent variable. However, the coefficient is not statistically significant. 
The Twelve Months Results

Table 8

TWELVEM MONTHS IMPACT OF PAYMENT METHODS AND
ABSOLUTE MERGER SIZE
$\left(\mathrm{R}_{\mathrm{p}, \mathrm{t}}-\mathrm{R}_{\mathrm{f}, \mathrm{t}}\right)=\beta_{0}^{\prime}-\beta_{1}{ }_{1} \mathrm{Merval}_{\mathrm{p}}-\beta_{2} \mathrm{D}+\varepsilon$

\begin{tabular}{|c|c|c|c|c|c|}
\hline \multicolumn{6}{|c|}{ Analysis of Variance } \\
\hline Multiple R & & 0.367 & & & \\
\hline Multiple R Squa & & 0.134 & & & \\
\hline Adjusted R Squa & & 0.019 & & & \\
\hline$\underline{\text { Standard error of }}$ & nate & 0.214 & & & \\
\hline Model & Sum of Squares & Df & Mean Square & $\mathrm{F}$ & Sig. \\
\hline Regression & 0.001 & 2 & 0.001 & 1.165 & 0.339 \\
\hline Residual & 0.007 & 15 & 0.000 & & \\
\hline Total & 0.008 & 17 & & & \\
\hline \multicolumn{6}{|c|}{ Variables in the Equation } \\
\hline \multicolumn{6}{|c|}{ Variables in the } \\
\hline Equation & B & Std.Error & Beta & $\mathrm{T}$ & Sig. \\
\hline Constant & 0.021 & 0.010 & & 2.180 & 0.046 \\
\hline Payment & -0.017 & 0.011 & -0.406 & -1.509 & 0.152 \\
\hline Absolute Size & $-2.29 \mathrm{E}-012$ & 0.000 & -0.239 & -0.886 & 0.389 \\
\hline
\end{tabular}

$\underline{\text { Summary. The regression equation characteristics of percentage stock excess }}$ return at twelve months indicates adjusted $\mathrm{R}^{2}$ of 0.019 . It suggests that only $1.9 \%$ of the variation in the percentage excess return is explained by the equation. The F value of 1.165 with shows that the data overall does not support the model.

$\underline{\text { Overall Trend of the Impact on Percentage Excess Returns }}$

In general, the study identifies a significant association between excess returns and payment methods and absolute merger size at three, six, and nine months post merger. The model (4) fits the data well and the results generally support hypothesis 
3(b). The coefficients of Betas represent the impact of the independent variables on the percentage excess returns of acquirers. More specifically, when comparing the Betas among all four different time frames, the impact of absolute size (-0.612) is greater than that of payment methods $(-0.574)$ in the relatively shorter term of three months. Yet the differences become reversed in the longer term.

Second, the negative impact of cash payment on hospitality acquirers decreases with time while the impact significance level dwindles as well. The negative impact of cash payment at three months is $-0.574(\mathrm{~T}=-2.534)$ as compared to that of twelve months at $-0.406(-1.509)$.

Third, stock payment offers yield relatively greater percentage returns to acquirers than cash payment offers with equal size control. Yet the differences decrease with time as well. After three months post merger, the differences closes from $8.4 \%$ to $4.3 \%$, to $3.5 \%$ at nine months post merger.

The results of the negative impact of cash offers are identifiable with the recent study of Slovin and others (2005) while challenge previous views on the positive impact of cash payment (Harris and Mayer, 1988, etc.).

Finally, the study discovers the important effect of absolute merger size on the excess percentage return and less significant effect of relative merger size. The results were in partial agreement with Asquith, Bruner, and Mullins (1983 and 1986) in which both forms of size were found relevant. 


\section{CHAPTER V}

\section{CONCLUSION}

The value-maximization behaviors of acquiring firms suggest that merger and acquisition activities create synergy for the acquired and acquiring firms. Previous studies (Hsu and Jang, 2006) selected the S\& P 500 index as the benchmark portfolio and found that neither in the long-term equity performance nor in the short-term accounting measures did acquiring lodging companies gain from the mergers from 1985 to 2000. This study incorporated sector indices. It is believed that the sector indices offered a more appropriate measure for the abnormal gains since the indices helped isolate the impact from the volatilities of the hospitality industry as a whole. This study found significant positive gains for the acquiring hospitality firms in the long term using industry indices from 1996 to 2007. The result supports the study of Canina (2001).

Previous payment studies on merger and acquisition have lead to mixed findings based on conflicting payment theories in general disciplines. The study found that cash offer acquirers and stock offer acquirers did not produce significantly different abnormal returns on equity for hospitality acquirers. This study attempted to control the size of merger and acquisition and the type of payment to study the impact on acquirers' excess return on equity. Absolute size was found to have significant impact on the excess returns of hospitality acquirers. The study also found the negative impact of cash offer more obvious closer to the merger announcement than in the long term of 12 months. 
Stock offers, on the other hand, were more preferable to acquirers' equity value overall. In addition, the significant negative impact of cash financing decreased greatly three months after merger and acquisition and its negative impact became negligible twelve months later.

It's a challenge to develop a theoretical model effectively testing the validities of the three theories of payment methods. The study on payment methods in merger and acquisition also involves complex data collection and filtering process. Some acquirers later became target companies. The role switch restricted access to their market values and stock performances twelve months or longer after the merger announcement. Other acquirers turn into private entities shortly after the period of interest in this study and their financial information were no longer available to the public. The mix of payment methods for many acquirers greatly limits the list of study.

Despite conflicting empirical studies (e.g., Canina, 2001; Sheel and Nagpal, 2000; Hsu and Jang, 2006; Yang and Kim, 2007), the hospitality industry continues to witness more firms diversifying their portfolios through merger and acquisition activities. One possible explanation is that the industry itself generally outperforms the general market, thus shareholders support management decisions to obtain greater market shares. Hospitality acquirers are striving to adjust to the highly saturated market, post merger management problems, and the higher volatilities of the industry to the broad market. Ultimately, hospitality top management needs to take into consideration that the goal is to maximize shareholders' value.

Future studies can conduct a comprehensive comparison among different models measuring abnormal returns such as buy-and-hold (Barber and Lyons, 1997) and Fama- 
French factors (Fama and French, 1993). Different results derived by different models can be studied. Given the fluctuations on the general stock market and the industrysensitive volatilities, future studies can also explore and categorize the differences of abnormal returns in event time and also in different industry sectors. 


\section{REFERENCES}

Asquith, P. (1983). Merger bids, uncertainty, and stockholder returns. Journal of Financial Economics, 11, 51-83.

Asquith, P., Burner, R.F., \& Mullins, D. W. (1990). Merger returns and the form of financing. Retrieved May 20, 2007, from http://dspace.mit.edu/handle/1721.1/2319.

Asquith, P., Bruner, R.F., \& Mullins, D.W. (1983). The gains to bidding firms from merger. Journal of Financial Economics, 11, 51-83.

Angelo, H.D., Angelo, L.D., \& Rice, E. (1984). Going private: Minority freezeouts and stockholder wealth. Journal of Law and Economics, 26 (1), 367-401.

Barber, M.B., \& Lyon, J.D. (1997). Detecting long-run abnormal stock returns: The empirical power and specification of test statistics. Journal of Financial Economics, 43,341-372.

Barshay, S. A, \& Falk, R. S. (Eds.). (2006). Mergers and acquisitions 2006: What you need to know now. New York: Practicing Law Institute.

Bradley, M. (1980). Interfirm tender offers and the market for corporate control. Journal of Business, 54, 345-376.

Canina, L. (2001). Acquisitions in the lodging industry: Good news for buyers and sellers. Cornell Hotel \& Restaurant Administration Quarterly, 42(6), 47-54.

Conn, R.L., \& Nielsen, L.F.. (1977). An empirical test of the Larson Gonedes exchange ration determination model. Journal of Finance, 32, 749-760. 
Dodd, P. (1980). Merger proposals, management discretion and stockholder wealth. Journal of Financial Economics, 8, 105-138.

Dodd, P., \& Ruback, R. (1977). Tender offers and stockholder returns. Journal of Financial Economics, 5,351-373.

Fama, E., \& French, K. (1993). Common risk factors in the returns on stocks and Bonds. Journal of Financial Economics, 33, 3-56.

Franks, J., Harris, R., \& Titman, S. (1991). The postmerger share-price performance of acquiring firms. Journal of Financial Economics, 29, 81-96.

Franks, J.R., Harris, R.S., \& Mayer, C. (1988). Means of Payment in Takeovers: Results for the United Kingdom and the United States. In Auerback, A. (Ed.), Corporate Takeovers: causes and consequences (pp. 221-258). Chicago: University of Chicago Press.

Gilson, R.J., Meyers, C.J., Stern, M., \& Black, E. B.S. (1995). The law and finance of corporate acquisition, ( $2^{\text {nd }}$ ed.). Westbury, New York: The Foundation Press.

Gordon, M., \& Yagil, J. (1981). Financial gains from conglomerate mergers. Research in Finance, 3, 103-142.

Grinblatt, M. (1989). A comparison of measures of abnormal performance on a sample of monthly mutual fund returns. Finance. Retrieved May 20 20007, from http://repositories.cdlib.org/anderson/fin/13-86.

Grinblatt, M., \& Titman, S. (1989). Mutual fund performance: An analysis of quarterly portfolio holdings. Journal of Business, 62, 393-417.

Hsu, L., \& Jang, S. (2006). Post-merger financial performance of the lodging industry. Proceedings of the 2006 11th Annual Graduate Education and Graduate Student 
Research Conference in Hospitality and Tourism, January 5-7, 2005, Seattle, USA. 11-20.

Jensen, M.C. (1968). The performance of mutual funds in the period 1945-1964. Journal of Finance, 23, 389-416.

Johnson, J.B., Joslyn, R.A., \& Reynolds, H.T. (2001). Political Science Research Methods (4th ed.). Washington D.C.: CQ Press.

Lehmann, B., \& Modest, D. (1987). Mutual fund performance evaluation: A comparison of benchmarks. Journal of Finance, 42, 233-265.

Lubatkin, M. (1983). Mergers and performance of the acquiring firm. The Academy of Management Review, 8 (2), 218-225.

Michel. A., \& Shaked, I. (1985). Evaluating merger performance. California Management Review, 27 (3), 109-118.

Myers, S.C., \& Majluf, N.J. (1984). Corporate financing and investment decisions when firms have information that investors do not have. Journal of Financial Economics, 13, 187-221.

North American Industry Classification System. United States, 2002. Executive office of the President. Office of Management and Budget. Lanham,MD: Bernan.

Sheel, A., \& Nagpal, A. (2000). The post-merger equity value performance of acquiring firms in the hospitality industry. The Journal of Hospitality Financial Management, $8(1), 37-45$.

Slovin, M., Sushka, M. E., \& Polonechek, J. A. (2006). Methods of payment in asset sales: Contracting with equity versus cash. The Journal of Finance. LX(5), 23852407. 
Sung, H.M. (1993). The effects of overpayment and form of financing on bidder returns in mergers and tender offers. The Journal of Financial Research, XVI (4), 351365.

Travlos, N.G. (1987). Corporate takeover bids, method of payment, and bidding firm's stock returns. Journal of Finance, 42, 943-63.

Wansley, J.W., Lane, W.R., \& Yang, H.C. (1983).Abnormal returns to acquired firms by type of acquisition and methods of payment. Financial Management, 12, 16-22.

Wansley, J.W., Lane, W.R., \& Yang, H.C. (1987). Gains to bidder firms in cash and securities transactions. The Financial Review, 22 (4), 403-414.

Ward's Business directory (Vols. 1-4). Belmont, CA : Information Access Co.

Yang, J \& Kim, G. W. (2007). Long-term post merger financial performance of the hospitality firms. 12th Annual Graduate Education and Graduate Students Research Conference in Hospitality and Tourism, January 4-6, 2007, Houston, U.S.A. 


\section{APPENDIX}

Appendix 1.

Studied Merger List \& Merger Value

$\begin{array}{ccc}\text { Acquirer Name } & \begin{array}{c}\text { Announced } \\ \text { Total Value } \\ (\mathrm{mil} .)\end{array} & \begin{array}{c}\text { Acquirer } \\ \text { Market Value } \\ (\mathrm{mil} .)\end{array} \\ \text { STRATEGIC HOTELS \& RESORTS } & 345 & 1,531 \\ \text { FELCOR LODGING TRUST INC } & 200 & 633 \\ \text { HOSPITALITY PROPERTIES TRUST } & 453 & 3,859 \\ \text { LASALLE HOTEL PROPERTIES } & 215 & 1,600 \\ \text { LA QUINTA CORP-PAIRED } & 412 & 1,616 \\ \text { MARRIOTT INTERNATIONAL-CL A } & 1,452 & 12,542 \\ \text { MORGANS HOTEL GROUP CO } & 770 & 633 \\ \text { SUNSTONE HOTEL INVESTORS INC } & 243 & 1,723 \\ \text { STATION CASINOS INC } & 232 & 4,323 \\ \text { HOST HOTELS \& RESORTS INC } & 3,324 & 10,814 \\ \text { BOYD GAMING CORP } & 1,284 & 2,431 \\ \text { HARRAH'S ENTERTAINMENT INC } & 9,380 & 13,969 \\ \text { HILTON HOTELS CORP } & 3,963 & 4,017 \\ \text { PATRIOT AMER HOSPITALITY INC } & 289 & 5,899 \\ \text { MGM MIRAGE } & 522 & 2,811 \\ \text { HARRAH'S ENTERTAINMENT INC } & 743 & 2,992 \\ \text { FELCOR LODGING TRUST INC } & 1,703 & 1,773 \\ \text { CAESARS ENTERTAINMENT INC } & 850 & 1,500\end{array}$


Appendix 2.

Acquirer historical stock price (Px), stock return (Rpt), stock excess return (Rpt-Rft), market indices return (Rmt), \& market indices excess return (Rmt-Rpt)

Appendix 2.1

Ameristar Casinos Inc (ASCA)

$\begin{array}{cccccc}\text { Date } & \text { Px Last } & \text { Rpt } & \text { Rmt } & \text { Rpt-Rft } & \text { Rmt-Rft } \\ 12 / 29 / 2000 & 2.56 & & & & \\ 1 / 31 / 2001 & 3.13 & 21.95 \% & 9.84 \% & 21.40 \% & 9.29 \% \\ 2 / 28 / 2001 & 3.19 & 2.00 \% & -8.52 \% & 1.54 \% & -8.99 \% \\ 3 / 30 / 2001 & 3.26 & 2.21 \% & -3.08 \% & 1.77 \% & -3.51 \% \\ 4 / 30 / 2001 & 4.25 & 30.46 \% & 7.82 \% & 30.03 \% & 7.39 \% \\ 5 / 31 / 2001 & 6.32 & 48.71 \% & 4.33 \% & 48.34 \% & 3.96 \% \\ 6 / 29 / 2001 & 8.00 & 26.58 \% & -0.56 \% & 26.24 \% & -0.90 \% \\ 7 / 31 / 2001 & 8.83 & 10.31 \% & 0.33 \% & 9.99 \% & 0.00 \% \\ 8 / 31 / 2001 & 7.71 & -12.63 \% & -3.77 \% & -12.95 \% & -4.08 \% \\ 9 / 28 / 2001 & 6.52 & -15.50 \% & -26.88 \% & -15.80 \% & -27.18 \% \\ 10 / 31 / 2001 & 8.59 & 31.85 \% & -1.85 \% & 31.63 \% & -2.07 \% \\ 11 / 30 / 2001 & 11.90 & 38.53 \% & 16.94 \% & 38.34 \% & 16.75 \% \\ 12 / 31 / 2001 & 12.53 & 5.25 \% & 9.04 \% & 5.08 \% & 8.86 \%\end{array}$


Appendix 2.2

Strategic Hotels and Resorts (BEE)

$\begin{array}{cccccc}\text { Date } & \text { Px Last } & \text { Rpt } & \text { Rmt } & \text { Rpt-Rft } & \text { Rmt-Rft } \\ 9 / 29 / 2006 & 19.88 & & & & \\ 10 / 31 / 2006 & 21.27 & 6.99 \% & 1.60 \% & 6.55 \% & 1.15 \% \\ 11 / 30 / 2006 & 21.75 & 2.26 \% & 5.17 \% & 1.81 \% & 4.73 \% \\ 12 / 29 / 2006 & 21.79 & 0.18 \% & -2.15 \% & -0.26 \% & -2.60 \% \\ 1 / 31 / 2007 & 21.52 & -1.24 \% & 5.27 \% & -1.68 \% & 4.82 \% \\ 2 / 28 / 2007 & 21.00 & -2.42 \% & -1.11 \% & -2.86 \% & -1.56 \% \\ 3 / 30 / 2007 & 22.87 & 8.90 \% & 1.91 \% & 8.46 \% & 1.47 \% \\ 4 / 30 / 2007 & 21.65 & -5.33 \% & -1.07 \% & -5.78 \% & -1.51 \% \\ 5 / 31 / 2007 & 23.32 & 7.71 \% & 1.76 \% & 7.27 \% & 1.32 \% \\ 6 / 29 / 2007 & 22.49 & -3.56 \% & -6.02 \% & -4.00 \% & -6.47 \% \\ 7 / 31 / 2007 & 21.28 & -5.38 \% & -8.83 \% & -5.82 \% & -9.28 \% \\ 8 / 31 / 2007 & 20.57 & -3.34 \% & 2.44 \% & -3.78 \% & 2.00 \% \\ 9 / 28 / 2007 & 20.59 & 0.10 \% & -0.74 \% & -0.38 \% & -1.22 \%\end{array}$


Appendix 2.3

\section{Boyd Gaming Corp (BYD)}

$\begin{array}{cccccc}\text { Date } & \text { Px Last } & \text { Rpt } & \text { Rft } & \text { Rpt-Rft } & \text { Rmt-Rft } \\ 7 / 30 / 2004 & 26.29 & & & & \\ 8 / 31 / 2004 & 27.15 & 3.27 \% & 0.02 \% & 3.15 \% & -0.10 \% \\ 9 / 30 / 2004 & 28.15 & 3.68 \% & 8.85 \% & 3.54 \% & 8.72 \% \\ 10 / 29 / 2004 & 33.49 & 18.97 \% & 6.36 \% & 18.82 \% & 6.21 \% \\ 11 / 30 / 2004 & 36.76 & 9.76 \% & 5.86 \% & 9.60 \% & 5.69 \% \\ 12 / 31 / 2004 & 41.65 & 13.30 \% & 10.90 \% & 13.11 \% & 10.71 \% \\ 1 / 31 / 2005 & 39.80 & -4.44 \% & -1.58 \% & -4.64 \% & -1.78 \% \\ 2 / 28 / 2005 & 49.01 & 23.14 \% & 2.95 \% & 22.92 \% & 2.74 \% \\ 3 / 31 / 2005 & 52.15 & 6.41 \% & 0.22 \% & 6.18 \% & 0.00 \% \\ 4 / 29 / 2005 & 52.78 & 1.21 \% & -6.65 \% & 0.97 \% & -6.89 \% \\ 5 / 31 / 2005 & 52.86 & 0.15 \% & 4.76 \% & -0.11 \% & 4.50 \% \\ 6 / 30 / 2005 & 51.13 & -3.27 \% & -5.80 \% & -3.53 \% & -6.06 \% \\ 7 / 29 / 2005 & 52.44 & 2.56 \% & 7.12 \% & 2.28 \% & 6.84 \%\end{array}$


Appendix 2.4

Felcor Lodging Trust Inc (FCH)

$\begin{array}{cccccc}\text { Date } & \text { Px Last } & \text { Rpt } & \text { Rmt } & \text { Rpt-Rft } & \text { Rmt-Rft } \\ 6 / 30 / 1997 & 37.25 & & & & \\ 7 / 31 / 1997 & 39.00 & 4.70 \% & 3.90 \% & 4.22 \% & 3.42 \% \\ 8 / 29 / 1997 & 38.00 & -2.56 \% & -0.91 \% & -3.03 \% & -1.38 \% \\ 9 / 30 / 1997 & 41.06 & 8.06 \% & 15.67 \% & 7.59 \% & 15.20 \% \\ 10 / 31 / 1997 & 36.63 & -10.81 \% & 0.52 \% & -11.28 \% & 0.05 \% \\ 11 / 28 / 1997 & 36.31 & -0.85 \% & -9.13 \% & -1.32 \% & -9.60 \% \\ 12 / 31 / 1997 & 35.50 & -2.24 \% & 3.71 \% & -2.73 \% & 3.21 \% \\ 1 / 30 / 1998 & 37.38 & 5.28 \% & -2.38 \% & 4.81 \% & -2.85 \% \\ 2 / 27 / 1998 & 35.88 & -4.01 \% & 1.75 \% & -4.48 \% & 1.28 \% \\ 3 / 31 / 1998 & 37.06 & 3.31 \% & -1.84 \% & 2.84 \% & -2.31 \% \\ 4 / 30 / 1998 & 35.00 & -5.56 \% & -5.63 \% & -6.04 \% & -6.10 \% \\ 5 / 29 / 1998 & 34.44 & -1.61 \% & -5.36 \% & -2.08 \% & -5.83 \% \\ 6 / 30 / 1998 & 31.38 & -8.89 \% & -0.25 \% & -9.36 \% & -0.72 \%\end{array}$


Appendix 2.5

Harrah's Entertainment Inc (HET)

$\begin{array}{cccccc}\text { Date } & \text { Px Last } & \text { Rpt } & \text { Rmt } & \text { Rpt-Rft } & \text { Rmt-Rft } \\ 6 / 30 / 2005 & 72.07 & & & & \\ 7 / 29 / 2005 & 78.74 & 9.25 \% & 7.12 \% & 8.98 \% & 6.84 \% \\ 8 / 31 / 2005 & 69.56 & -11.66 \% & -9.20 \% & -11.95 \% & -9.49 \% \\ 9 / 30 / 2005 & 65.19 & -6.28 \% & -2.33 \% & -6.59 \% & -2.64 \% \\ 10 / 31 / 2005 & 60.48 & -7.23 \% & -5.36 \% & -7.55 \% & -5.68 \% \\ 11 / 30 / 2005 & 68.09 & 12.58 \% & 12.09 \% & 12.24 \% & 11.75 \% \\ 12 / 30 / 2005 & 71.29 & 4.70 \% & 1.30 \% & 4.34 \% & 0.95 \% \\ 1 / 31 / 2006 & 73.60 & 3.24 \% & 6.90 \% & 2.87 \% & 6.53 \% \\ 2 / 28 / 2006 & 71.92 & -2.28 \% & 0.65 \% & -2.66 \% & 0.27 \% \\ 3 / 31 / 2006 & 77.96 & 8.40 \% & 8.23 \% & 8.01 \% & 7.84 \% \\ 4 / 28 / 2006 & 81.64 & 4.72 \% & 5.83 \% & 4.32 \% & 5.43 \% \\ 5 / 31 / 2006 & 76.04 & -6.86 \% & -0.97 \% & -7.28 \% & -1.39 \% \\ 6 / 30 / 2006 & 71.18 & -6.39 \% & 2.22 \% & -6.82 \% & 1.79 \%\end{array}$


Appendix 2.6

Hilton Hotels Corp (HLY)

$\begin{array}{cccccc}\text { Date } & \text { Px Last } & \text { Rpt } & \text { Rmt } & \text { Rpt-Rft } & \text { Rmt-Rft } \\ 12 / 31 / 1999 & 9.56 & & & & \\ 1 / 31 / 2000 & 8.44 & -11.76 \% & -2.92 \% & -12.25 \% & -3.41 \% \\ 2 / 29 / 2000 & 7.00 & -17.04 \% & -8.80 \% & -17.53 \% & -9.29 \% \\ 3 / 31 / 2000 & 7.75 & 10.71 \% & 10.49 \% & 10.22 \% & 10.00 \% \\ 4 / 28 / 2000 & 8.44 & 8.87 \% & 11.11 \% & 8.36 \% & 10.60 \% \\ 5 / 31 / 2000 & 8.50 & 0.74 \% & 6.40 \% & 0.22 \% & 5.87 \% \\ 6 / 30 / 2000 & 9.38 & 10.29 \% & 3.58 \% & 9.74 \% & 3.03 \% \\ 7 / 31 / 2000 & 10.25 & 9.33 \% & 9.24 \% & 8.78 \% & 8.68 \% \\ 8 / 31 / 2000 & 10.02 & -2.25 \% & -1.38 \% & -2.80 \% & -1.93 \% \\ 9 / 29 / 2000 & 11.81 & 17.89 \% & -2.44 \% & 17.34 \% & -3.00 \% \\ 10 / 31 / 2000 & 9.50 & -19.58 \% & 1.51 \% & -20.13 \% & 0.96 \% \\ 11 / 30 / 2000 & 9.38 & -1.32 \% & 3.35 \% & -1.87 \% & 2.80 \% \\ 12 / 29 / 2000 & 10.50 & 12.00 \% & 5.72 \% & 11.43 \% & 5.16 \%\end{array}$


Appendix 2.7

Hospitality Properties Trust (HPT)

$\begin{array}{cccccc}\text { Date } & \text { Px Last } & \text { Rpt } & \text { Rmt } & \text { Rpt-Rft } & \text { Rmt-Rft } \\ 2 / 28 / 2005 & 38.93 & & & & \\ 3 / 31 / 2005 & 37.91 & -2.63 \% & -0.09 \% & -2.85 \% & -0.32 \% \\ 4 / 29 / 2005 & 39.22 & 3.47 \% & 1.63 \% & 3.23 \% & 1.39 \% \\ 5 / 31 / 2005 & 41.23 & 5.12 \% & 3.20 \% & 4.86 \% & 2.95 \% \\ 6 / 30 / 2005 & 41.37 & 0.34 \% & 4.21 \% & 0.08 \% & 3.95 \% \\ 7 / 29 / 2005 & 41.68 & 0.75 \% & 5.03 \% & 0.47 \% & 4.75 \% \\ 8 / 31 / 2005 & 40.70 & -2.34 \% & -3.76 \% & -2.64 \% & -4.06 \% \\ 9 / 30 / 2005 & 40.23 & -1.15 \% & -2.09 \% & -1.46 \% & -2.40 \% \\ 10 / 31 / 2005 & 37.27 & -7.37 \% & -2.94 \% & -7.69 \% & -3.26 \% \\ 11 / 30 / 2005 & 38.67 & 3.75 \% & 5.82 \% & 3.41 \% & 5.48 \% \\ 12 / 30 / 2005 & 37.64 & -2.65 \% & 2.39 \% & -3.00 \% & 2.03 \% \\ 1 / 31 / 2006 & 40.24 & 6.91 \% & 7.62 \% & 6.54 \% & 7.26 \% \\ 2 / 28 / 2006 & 41.77 & 3.80 \% & -0.12 \% & 3.42 \% & -0.50 \%\end{array}$


Appendix 2.8

Host Hotels \& Resorts Inc (HST)

$\begin{array}{cccccc}\text { Date } & \text { Px Last } & \text { Rpt } & \text { Rmt } & \text { Rpt-Rft } & \text { Rmt-Rft } \\ 4 / 28 / 2006 & 21.02 & & & & \\ 5 / 31 / 2006 & 20.07 & -4.52 \% & -3.24 \% & -4.94 \% & -3.66 \% \\ 6 / 30 / 2006 & 21.87 & 8.97 \% & 6.77 \% & 8.54 \% & 6.35 \% \\ 7 / 31 / 2006 & 21.22 & -2.97 \% & -2.56 \% & -3.42 \% & -3.00 \% \\ 8 / 31 / 2006 & 22.54 & 6.22 \% & 4.27 \% & 5.77 \% & 3.82 \% \\ 9 / 29 / 2006 & 22.93 & 1.73 \% & 0.27 \% & 1.29 \% & -0.17 \% \\ 10 / 31 / 2006 & 23.06 & 0.57 \% & 1.60 \% & 0.12 \% & 1.15 \% \\ 11 / 30 / 2006 & 25.22 & 9.37 \% & 5.17 \% & 8.92 \% & 4.73 \% \\ 12 / 29 / 2006 & 24.55 & -2.66 \% & -2.15 \% & -3.10 \% & -2.60 \% \\ 1 / 31 / 2007 & 26.47 & 7.82 \% & 5.27 \% & 7.38 \% & 4.82 \% \\ 2 / 28 / 2007 & 26.28 & -0.72 \% & -1.11 \% & -1.16 \% & -1.56 \% \\ 3 / 30 / 2007 & 26.31 & 0.11 \% & 1.91 \% & -0.33 \% & 1.47 \% \\ 4 / 30 / 2007 & 25.64 & -2.55 \% & -1.07 \% & -2.99 \% & -1.51 \%\end{array}$


Appendix 2.9

Lasalle Hotel Properties (LHO)

$\begin{array}{cccccc}\text { Date } & \text { Px Last } & \text { Rpt } & \text { Rmt } & \text { Rpt-Rft } & \text { Rmt-Rft } \\ 3 / 31 / 2006 & 41.00 & & & & \\ 4 / 28 / 2006 & 43.73 & 6.66 \% & -1.02 \% & 6.26 \% & -1.42 \% \\ 5 / 31 / 2006 & 41.53 & -5.03 \% & -3.24 \% & -5.45 \% & -3.66 \% \\ 6 / 30 / 2006 & 46.30 & 11.49 \% & 6.77 \% & 11.06 \% & 6.35 \% \\ 7 / 31 / 2006 & 41.31 & -10.78 \% & -2.56 \% & -11.22 \% & -3.00 \% \\ 8 / 31 / 2006 & 43.94 & 6.37 \% & 4.27 \% & 5.92 \% & 3.82 \% \\ 9 / 29 / 2006 & 43.34 & -1.37 \% & 0.27 \% & -1.81 \% & -0.17 \% \\ 10 / 31 / 2006 & 42.25 & -2.51 \% & 1.60 \% & -2.96 \% & 1.15 \% \\ 11 / 30 / 2006 & 44.10 & 4.38 \% & 5.17 \% & 3.94 \% & 4.73 \% \\ 12 / 29 / 2006 & 45.85 & 3.97 \% & -2.15 \% & 3.52 \% & -2.60 \% \\ 1 / 31 / 2007 & 47.61 & 3.84 \% & 5.27 \% & 3.40 \% & 4.82 \% \\ 2 / 28 / 2007 & 44.43 & -6.68 \% & -1.11 \% & -7.12 \% & -1.56 \% \\ 3 / 30 / 2007 & 46.36 & 4.34 \% & 1.91 \% & 3.90 \% & 1.47 \%\end{array}$


Appendix 2.10

La Quita Corp-Paired (LQI)

$\begin{array}{cccccc}\text { Date } & \text { Date } & \text { Px Last } & \text { Rpt } & \text { Rmt } & \text { Rpt-Rft } \\ 9 / 30 / 2004 & 9 / 30 / 2004 & 7.80 & & & \\ 10 / 29 / 2004 & 10 / 29 / 2004 & 8.05 & 3.21 \% & -22.29 \% & 3.05 \% \\ 11 / 30 / 2004 & 11 / 30 / 2004 & 8.05 & 0.00 \% & -17.74 \% & -0.17 \% \\ 12 / 31 / 2004 & 12 / 31 / 2004 & 9.09 & 12.92 \% & -8.78 \% & 12.73 \% \\ 1 / 31 / 2005 & 1 / 31 / 2005 & 8.69 & -4.40 \% & -10.21 \% & -4.60 \% \\ 2 / 28 / 2005 & 2 / 28 / 2005 & 9.25 & 6.44 \% & -7.56 \% & 6.23 \% \\ 3 / 31 / 2005 & 3 / 31 / 2005 & 8.50 & -8.11 \% & -7.36 \% & -8.33 \% \\ 4 / 29 / 2005 & 4 / 29 / 2005 & 8.70 & 2.35 \% & -13.51 \% & 2.11 \% \\ 5 / 31 / 2005 & 5 / 31 / 2005 & 8.67 & -0.34 \% & -9.40 \% & -0.60 \% \\ 6 / 30 / 2005 & 6 / 30 / 2005 & 9.33 & 7.61 \% & -14.66 \% & 7.35 \% \\ 7 / 29 / 2005 & 7 / 29 / 2005 & 9.00 & -3.54 \% & -8.58 \% & -3.82 \% \\ 8 / 31 / 2005 & 8 / 31 / 2005 & 8.45 & -6.11 \% & -16.99 \% & -6.40 \% \\ 9 / 30 / 2005 & 9 / 30 / 2005 & 8.69 & 2.84 \% & -18.93 \% & 2.53 \%\end{array}$


Appendix 2.11

Marriott International-CL A (MAR)

$\begin{array}{cccccc}\text { Date } & \text { Px Last } & \text { Rpt } & \text { Rmt } & \text { Rpt-Rft } & \text { Rmt-Rft } \\ 6 / 30 / 2005 & 34.11 & & & & \\ 7 / 29 / 2005 & 34.24 & 0.37 \% & 7.12 \% & 0.09 \% & 6.84 \% \\ 8 / 31 / 2005 & 31.61 & -7.68 \% & -9.20 \% & -7.98 \% & -9.49 \% \\ 9 / 30 / 2005 & 31.50 & -0.33 \% & -2.33 \% & -0.64 \% & -2.64 \% \\ 10 / 31 / 2005 & 29.81 & -5.37 \% & -5.36 \% & -5.69 \% & -5.68 \% \\ 11 / 30 / 2005 & 32.31 & 8.37 \% & 12.09 \% & 8.03 \% & 11.75 \% \\ 12 / 30 / 2005 & 33.49 & 3.65 \% & 1.30 \% & 3.29 \% & 0.95 \% \\ 1 / 31 / 2006 & 33.32 & -0.49 \% & 6.90 \% & -0.86 \% & 6.53 \% \\ 2 / 28 / 2006 & 34.20 & 2.64 \% & 0.65 \% & 2.26 \% & 0.27 \% \\ 3 / 31 / 2006 & 34.30 & 0.29 \% & 8.23 \% & -0.09 \% & 7.84 \% \\ 4 / 28 / 2006 & 36.54 & 6.52 \% & 5.83 \% & 6.11 \% & 5.43 \% \\ 5 / 31 / 2006 & 36.17 & -1.01 \% & -0.97 \% & -1.43 \% & -1.39 \% \\ 6 / 30 / 2006 & 38.12 & 5.41 \% & 2.22 \% & 4.98 \% & 1.79 \%\end{array}$


Appendix 2.12

Morgans Hotels Group Co (MHGC)

$\begin{array}{cccccc}\text { Date } & \text { Px Last } & \text { Rpt } & \text { Rmt } & \text { Rpt-Rft } & \text { Rmt-Rft } \\ 2 / 28 / 2007 & 17.46 & & & & \\ 3 / 30 / 2007 & 21.01 & 20.33 \% & -0.12 \% & 19.89 \% & -0.57 \% \\ 4 / 30 / 2007 & 22.15 & 5.43 \% & -1.40 \% & 4.98 \% & -1.85 \% \\ 5 / 31 / 2007 & 24.58 & 10.97 \% & 2.39 \% & 10.53 \% & 1.94 \% \\ 6 / 29 / 2007 & 24.38 & -0.81 \% & -2.43 \% & -1.26 \% & -2.87 \% \\ 7 / 31 / 2007 & 19.29 & -20.88 \% & 1.71 \% & -21.32 \% & 1.27 \% \\ 8 / 31 / 2007 & 19.28 & -0.05 \% & 7.58 \% & -0.50 \% & 7.14 \% \\ 9 / 28 / 2007 & 21.75 & 12.81 \% & 10.95 \% & 12.33 \% & 10.47 \% \\ 10 / 31 / 2007 & 22.76 & 4.64 \% & 0.53 \% & 4.22 \% & 0.10 \% \\ 11 / 30 / 2007 & 18.49 & -18.76 \% & -10.03 \% & -19.15 \% & -10.42 \% \\ 12 / 31 / 2007 & 19.28 & 4.27 \% & -8.02 \% & 3.84 \% & -8.46 \%\end{array}$


Appendix 2.13

Patriot Amer Hospitality Inc (PAH)

$\begin{array}{cccccc}\text { Date } & \text { Px Last } & \text { Rpt } & \text { Rmt } & \text { Rpt-Rft } & \text { Rmt-Rft } \\ 7 / 31 / 1997 & 24.92 & & & & \\ 8 / 29 / 1997 & 24.36 & -2.26 \% & -0.91 \% & -2.72 \% & -1.38 \% \\ 9 / 30 / 1997 & 31.85 & 30.77 \% & 15.67 \% & 30.30 \% & 15.20 \% \\ 10 / 31 / 1997 & 32.98 & 3.53 \% & 0.52 \% & 3.06 \% & 0.05 \% \\ 11 / 28 / 1997 & 31.23 & -5.30 \% & -9.13 \% & -5.77 \% & -9.60 \% \\ 12 / 31 / 1997 & 28.80 & -7.80 \% & 3.71 \% & -8.30 \% & 3.21 \% \\ 1 / 30 / 1998 & 25.61 & -11.06 \% & -2.38 \% & -11.54 \% & -2.85 \% \\ 2 / 27 / 1998 & 24.98 & -2.44 \% & 1.75 \% & -2.91 \% & 1.28 \% \\ 3 / 31 / 1998 & 26.98 & 8.00 \% & -1.84 \% & 7.53 \% & -2.31 \% \\ 4 / 30 / 1998 & 25.23 & -6.48 \% & -5.63 \% & -6.96 \% & -6.10 \% \\ 5 / 29 / 1998 & 23.92 & -5.20 \% & -5.36 \% & -5.67 \% & -5.83 \% \\ 6 / 30 / 1998 & 23.92 & 0.00 \% & -0.25 \% & -0.47 \% & -0.72 \% \\ 7 / 31 / 1998 & 18.99 & -20.63 \% & -14.39 \% & -21.10 \% & -14.86 \%\end{array}$


Appendix 2.14

Sunstone Hotel Investors Inc (SHO)

$\begin{array}{cccccc}\text { Date } & \text { Px Last } & \text { Rpt } & \text { Rmt } & \text { Rpt-Rft } & \text { Rmt-Rft } \\ 3 / 31 / 2006 & 28.97 & & & & \\ 4 / 28 / 2006 & 28.74 & -0.00794 & -0.01021 & -0.01196 & -0.01423 \\ 5 / 31 / 2006 & 27.7 & -0.03619 & -0.03235 & -0.04039 & -0.03655 \\ 6 / 30 / 2006 & 29.06 & 0.049097 & 0.067727 & 0.044839 & 0.063468 \\ 7 / 31 / 2006 & 28.36 & -0.02409 & -0.0256 & -0.02853 & -0.03004 \\ 8 / 31 / 2006 & 29.9 & 0.054302 & 0.04271 & 0.04981 & 0.038217 \\ 9 / 29 / 2006 & 29.72 & -0.00602 & 0.002694 & -0.01046 & -0.00175 \\ 10 / 31 / 2006 & 29.46 & -0.00875 & 0.015961 & -0.01318 & 0.011526 \\ 11 / 30 / 2006 & 27.88 & -0.05363 & 0.051719 & -0.05807 & 0.047285 \\ 12 / 29 / 2006 & 26.73 & -0.04125 & -0.02152 & -0.04571 & -0.02598 \\ 1 / 31 / 2007 & 28.29 & 0.058361 & 0.052675 & 0.053926 & 0.04824 \\ 2 / 28 / 2007 & 28.34 & 0.001767 & -0.01113 & -0.00267 & -0.01556 \\ 3 / 30 / 2007 & 27.26 & -0.03811 & 0.019094 & -0.04254 & 0.014661\end{array}$


Appendix 2.15

Station Casinos Inc (STN)

$\begin{array}{cccccc}\text { Date } & \text { Px Last } & \text { Rpt } & \text { Rmt } & \text { Rpt-Rft } & \text { Rmt-Rft } \\ 4 / 28 / 2006 & 77.08 & & & & \\ 5 / 31 / 2006 & 73.00 & -5.29 \% & -0.97 \% & -5.71 \% & -1.39 \% \\ 6 / 30 / 2006 & 68.08 & -6.74 \% & 2.22 \% & -7.17 \% & 1.79 \% \\ 7 / 31 / 2006 & 54.86 & -19.42 \% & -14.75 \% & -19.86 \% & -15.19 \% \\ 8 / 31 / 2006 & 58.25 & 6.18 \% & 7.34 \% & 5.73 \% & 6.89 \% \\ 9 / 29 / 2006 & 57.83 & -0.72 \% & 2.42 \% & -1.17 \% & 1.98 \% \\ 10 / 31 / 2006 & 60.30 & 4.27 \% & 8.25 \% & 3.83 \% & 7.81 \% \\ 11 / 30 / 2006 & 68.04 & 12.84 \% & 14.62 \% & 12.39 \% & 14.18 \% \\ 12 / 29 / 2006 & 81.67 & 20.03 \% & 3.82 \% & 19.59 \% & 3.37 \% \\ 1 / 31 / 2007 & 83.20 & 1.87 \% & 9.37 \% & 1.43 \% & 8.93 \% \\ 2 / 28 / 2007 & 86.29 & 3.71 \% & -4.57 \% & 3.27 \% & -5.01 \% \\ 3 / 30 / 2007 & 86.57 & 0.32 \% & -0.12 \% & -0.12 \% & -0.57 \% \\ 4 / 30 / 2007 & 87.00 & 0.50 \% & -1.40 \% & 0.05 \% & -1.85 \%\end{array}$


Appendix 2.16

MGM Mirage (MGM)

\begin{tabular}{lccccc} 
Date & Px Last & \multicolumn{1}{l}{ Rpt } & Rmt & Rpt-Rft & Rmt-Rft \\
$3 / 31 / 1999$ & 8.41 & & & & \\
$4 / 30 / 1999$ & 11.00 & $30.85 \%$ & $17.97 \%$ & $30.44 \%$ & $17.56 \%$ \\
$5 / 31 / 1999$ & 10.50 & $-4.55 \%$ & $-10.46 \%$ & $-4.95 \%$ & $-10.87 \%$ \\
$6 / 30 / 1999$ & 12.25 & $16.67 \%$ & $2.20 \%$ & $16.25 \%$ & $1.79 \%$ \\
$7 / 30 / 1999$ & 11.30 & $-7.78 \%$ & $-9.04 \%$ & $-8.22 \%$ & $-9.48 \%$ \\
$8 / 31 / 1999$ & 12.28 & $8.71 \%$ & $-4.81 \%$ & $8.28 \%$ & $-5.24 \%$ \\
$9 / 30 / 1999$ & 12.78 & $4.07 \%$ & $-4.35 \%$ & $3.62 \%$ & $-4.80 \%$ \\
$10 / 29 / 1999$ & 12.75 & $-0.24 \%$ & $0.42 \%$ & $-0.69 \%$ & $-0.03 \%$ \\
$11 / 30 / 1999$ & 12.34 & $-3.19 \%$ & $-2.34 \%$ & $-3.64 \%$ & $-2.79 \%$ \\
$12 / 31 / 1999$ & 12.58 & $1.90 \%$ & $-0.47 \%$ & $1.36 \%$ & $-1.01 \%$ \\
$1 / 31 / 2000$ & 10.34 & $-17.76 \%$ & $-2.92 \%$ & $-18.25 \%$ & $-3.41 \%$ \\
$2 / 29 / 2000$ & 9.94 & $-3.93 \%$ & $-8.80 \%$ & $-4.42 \%$ & $-9.29 \%$ \\
$3 / 31 / 2000$ & 12.00 & $20.75 \%$ & $10.49 \%$ & $20.26 \%$ & $10.00 \%$
\end{tabular}


Appendix 2.17

Harrah's Entertainment Inc (HET)

$\begin{array}{cccccc}\text { Date } & \text { Px Last } & \text { Rpt } & \text { Rmt } & \text { Rpt-Rft } & \text { Rmt-Rft } \\ 1 / 29 / 1999 & 14.88 & & & & \\ 2 / 26 / 1999 & 16.69 & 12.18 \% & 9.16 \% & 11.77 \% & 8.75 \% \\ 3 / 31 / 1999 & 19.06 & 14.23 \% & -5.10 \% & 13.82 \% & -5.51 \% \\ 4 / 30 / 1999 & 22.00 & 15.41 \% & 17.97 \% & 15.00 \% & 17.56 \% \\ 5 / 31 / 1999 & 21.63 & -1.70 \% & -10.46 \% & -2.11 \% & -10.87 \% \\ 6 / 30 / 1999 & 22.06 & 2.02 \% & 2.20 \% & 1.61 \% & 1.79 \% \\ 7 / 30 / 1999 & 21.31 & -3.40 \% & -9.04 \% & -3.84 \% & -9.48 \% \\ 8 / 31 / 1999 & 22.50 & 5.57 \% & -4.81 \% & 5.14 \% & -5.24 \% \\ 9 / 30 / 1999 & 27.75 & 23.33 \% & -4.35 \% & 22.89 \% & -4.80 \% \\ 10 / 29 / 1999 & 28.94 & 4.28 \% & 0.42 \% & 3.83 \% & -0.03 \% \\ 11 / 30 / 1999 & 27.63 & -4.54 \% & -2.34 \% & -4.99 \% & -2.79 \% \\ 12 / 31 / 1999 & 26.44 & -4.30 \% & -0.47 \% & -4.84 \% & -1.01 \% \\ 1 / 31 / 2000 & 19.94 & -24.59 \% & -2.92 \% & -25.07 \% & -3.41 \%\end{array}$


Appendix 2.18

Caesars Entertainment Inc (CZR)

$\begin{array}{cccccc}\text { Date } & \text { Px Last } & \text { Rpt } & \text { Rmt } & \text { Rpt-Rft } & \text { Rmt-Rft } \\ 1 / 29 / 1999 & 6.88 & & & & \\ 2 / 26 / 1999 & 7.50 & 9.09 \% & 9.16 \% & 8.68 \% & 8.75 \% \\ 3 / 31 / 1999 & 7.56 & 0.83 \% & -5.10 \% & 0.42 \% & -5.51 \% \\ 4 / 30 / 1999 & 10.81 & 42.98 \% & 17.97 \% & 42.56 \% & 17.56 \% \\ 5 / 31 / 1999 & 10.50 & -2.89 \% & -10.46 \% & -3.30 \% & -10.87 \% \\ 6 / 30 / 1999 & 9.56 & -8.97 \% & 2.20 \% & -9.38 \% & 1.79 \% \\ 7 / 30 / 1999 & 10.19 & 6.58 \% & -9.04 \% & 6.14 \% & -9.48 \% \\ 8 / 31 / 1999 & 11.50 & 12.88 \% & -4.81 \% & 12.45 \% & -5.24 \% \\ 9 / 30 / 1999 & 12.50 & 8.70 \% & -4.35 \% & 8.25 \% & -4.80 \% \\ 10 / 29 / 1999 & 13.13 & 5.00 \% & 0.42 \% & 4.55 \% & -0.03 \% \\ 11 / 30 / 1999 & 12.88 & -1.90 \% & -2.34 \% & -2.36 \% & -2.79 \% \\ 12 / 31 / 1999 & 12.50 & -2.91 \% & -0.47 \% & -3.45 \% & -1.01 \% \\ 1 / 31 / 2000 & 10.50 & -16.00 \% & -2.92 \% & -16.49 \% & -3.41 \%\end{array}$


Appendix 2.19

Felcor Lodging Trust Inc (FCH)

$\begin{array}{cccccc}\text { Date } & \text { Px Last } & \text { Rpt } & \text { Rmt } & \text { Rpt-Rft } & \text { Rmt-Rft } \\ 12 / 31 / 1998 & 23.00 & & & & \\ 1 / 29 / 1999 & 21.81 & -5.16 \% & 9.44 \% & -5.59 \% & 9.02 \% \\ 2 / 26 / 1999 & 23.63 & 8.31 \% & 9.16 \% & 7.90 \% & 8.75 \% \\ 3 / 31 / 1999 & 23.19 & -1.85 \% & -5.10 \% & -2.27 \% & -5.51 \% \\ 4 / 30 / 1999 & 23.94 & 3.23 \% & 17.97 \% & 2.82 \% & 17.56 \% \\ 5 / 31 / 1999 & 22.69 & -5.22 \% & -10.46 \% & -5.63 \% & -10.87 \% \\ 6 / 30 / 1999 & 20.75 & -8.54 \% & 2.20 \% & -8.95 \% & 1.79 \% \\ 7 / 30 / 1999 & 19.50 & -6.02 \% & -9.04 \% & -6.46 \% & -9.48 \% \\ 8 / 31 / 1999 & 17.94 & -8.01 \% & -4.81 \% & -8.45 \% & -5.24 \% \\ 9 / 30 / 1999 & 17.50 & -2.44 \% & -4.35 \% & -2.89 \% & -4.80 \% \\ 10 / 29 / 1999 & 17.00 & -2.86 \% & 0.42 \% & -3.31 \% & -0.03 \% \\ 11 / 30 / 1999 & 17.00 & 0.00 \% & -2.34 \% & -0.45 \% & -2.79 \% \\ 12 / 31 / 1999 & 17.50 & 2.94 \% & -0.47 \% & 2.40 \% & -1.01 \%\end{array}$


Appendix 3.

Lodging-industry Merger and Acquisition Trend 1982 to 2000 (in millions)

\begin{tabular}{|c|c|c|c|c|}
\hline \multirow[b]{2}{*}{ Year } & \multicolumn{2}{|c|}{ Private Sectors } & \multicolumn{2}{|c|}{$\underline{\text { Public Sector }}$} \\
\hline & No. of $\mathrm{M} \& \mathrm{~A}$ & Total Value & N0. of M\& A & Total Value \\
\hline 1982 & 0 & $\$ 0$ & 1 & $\$ 152.4$ \\
\hline 1983 & 1 & 286.3 & 1 & 137.4 \\
\hline 1984 & 0 & 0 & 2 & 316.0 \\
\hline 1985 & 0 & 0 & 3 & 460.3 \\
\hline 1986 & 0 & 0 & 2 & $1,065.0$ \\
\hline 1987 & 0 & 0 & 0 & 0 \\
\hline 1988 & 2 & 11.6 & 2 & 39.1 \\
\hline 1989 & 0 & 0 & 1 & 55.5 \\
\hline 1990 & 1 & 48.4 & 0 & 0 \\
\hline 1991 & 0 & 0 & 0 & 0 \\
\hline 1992 & 0 & 0 & 1 & 4.8 \\
\hline 1993 & 2 & 29.7 & 0 & 0 \\
\hline 1994 & 3 & 199.9 & 2 & 80.2 \\
\hline 1995 & 1 & 2.5 & 4 & 193.9 \\
\hline 1996 & 1 & 1.5 & 3 & $4,934.5$ \\
\hline 1997 & 0 & 0 & 7 & $15,559.6$ \\
\hline 1998 & 1 & 1.4 & 10 & $25,011.7$ \\
\hline 1999 & 3 & 3,734 & 2 & $1,093.0$ \\
\hline 2000 & 1 & 428.3 & N/A & N/A \\
\hline
\end{tabular}

Source: Canina (2001). 
Appendix 4.

Indices Comparison 1999-2007

\begin{tabular}{|c|c|c|c|c|c|c|}
\hline Date & $\begin{array}{c}\text { Lodging } \\
\text { Px Last }\end{array}$ & $\begin{array}{l}\text { REITs } \\
\text { Px Last }\end{array}$ & $\begin{array}{c}\text { S\&P } 500 \\
\text { Px Last }\end{array}$ & $\begin{array}{c}\text { Lodging } \\
\text { Px Last }\end{array}$ & $\begin{array}{l}\text { REITs } \\
\text { Px Last }\end{array}$ & $\begin{array}{c}\text { S \& P } 500 \\
\text { Px Last }\end{array}$ \\
\hline 1/29/1999 & 100.00 & 100.00 & 100.00 & 109.44 & 79.26 & 1279.64 \\
\hline 2/26/1999 & 109.16 & 97.94 & 96.77 & 119.47 & 77.63 & 1238.33 \\
\hline 3/31/1999 & 103.60 & 97.40 & 100.53 & 113.38 & 77.20 & 1286.37 \\
\hline 4/30/1999 & 122.22 & 109.49 & 104.34 & 133.76 & 86.78 & 1335.18 \\
\hline 5/31/1999 & 109.44 & 105.51 & 101.73 & 119.77 & 83.63 & 1301.84 \\
\hline 6/30/1999 & 111.85 & 100.81 & 107.27 & 122.41 & 79.90 & 1372.71 \\
\hline 7/30/1999 & 101.74 & 93.43 & 103.84 & 111.34 & 74.05 & 1328.72 \\
\hline 8/31/1999 & 96.85 & 87.35 & 103.19 & 105.99 & 69.23 & 1320.41 \\
\hline 9/30/1999 & 92.64 & 82.65 & 100.24 & 101.38 & 65.51 & 1282.71 \\
\hline 10/29/1999 & 93.03 & 80.71 & 106.51 & 101.81 & 63.97 & 1362.93 \\
\hline 11/30/1999 & 90.85 & 78.73 & 108.54 & 99.43 & 62.40 & 1388.91 \\
\hline 12/31/1999 & 90.42 & 76.41 & 114.82 & 98.96 & 60.56 & 1469.25 \\
\hline $1 / 31 / 2000$ & 87.78 & 79.60 & 108.97 & 96.07 & 63.09 & 1394.46 \\
\hline 2/29/2000 & 80.06 & 77.86 & 106.78 & 87.62 & 61.71 & 1366.42 \\
\hline $3 / 31 / 2000$ & 88.46 & 80.24 & 117.11 & 96.81 & 63.60 & 1498.58 \\
\hline $4 / 28 / 2000$ & 98.29 & 90.65 & 113.50 & 107.57 & 71.85 & 1452.43 \\
\hline $5 / 31 / 2000$ & 104.58 & 88.82 & 111.02 & 114.45 & 70.40 & 1420.60 \\
\hline $6 / 30 / 2000$ & 108.32 & 88.33 & 113.67 & 118.55 & 70.01 & 1454.60 \\
\hline 7/31/2000 & 118.33 & 98.03 & 111.82 & 129.50 & 77.70 & 1430.83 \\
\hline $8 / 31 / 2000$ & 116.69 & 95.14 & 118.60 & 127.71 & 75.41 & 1517.68 \\
\hline $9 / 29 / 2000$ & 113.84 & 96.61 & 112.26 & 124.59 & 76.57 & 1436.51 \\
\hline $10 / 31 / 2000$ & 115.56 & 91.21 & 111.70 & 126.47 & 72.29 & 1429.40 \\
\hline $11 / 30 / 2000$ & 119.44 & 93.89 & 102.76 & 130.71 & 74.42 & 1314.95 \\
\hline $12 / 29 / 2000$ & 126.27 & 100.16 & 103.18 & 138.19 & 79.39 & 1320.28 \\
\hline $1 / 31 / 2001$ & 138.70 & 107.49 & 106.75 & 151.79 & 85.20 & 1366.01 \\
\hline 2/28/2001 & 126.87 & 103.90 & 96.90 & 138.85 & 82.35 & 1239.94 \\
\hline 3/30/2001 & 122.97 & 101.16 & 90.68 & 134.58 & 80.18 & 1160.33 \\
\hline 4/30/2001 & 132.58 & 103.67 & 97.64 & 145.10 & 82.17 & 1249.46 \\
\hline $5 / 31 / 2001$ & 138.32 & 109.34 & 98.14 & 151.38 & 86.66 & 1255.82 \\
\hline $6 / 29 / 2001$ & 137.55 & 110.17 & 95.68 & 150.53 & 87.32 & 1224.42 \\
\hline $7 / 31 / 2001$ & 137.99 & 106.02 & 94.65 & 151.02 & 84.03 & 1211.23 \\
\hline $8 / 31 / 2001$ & 132.79 & 105.30 & 88.59 & 145.33 & 83.46 & 1133.58 \\
\hline 9/28/2001 & 97.10 & 69.15 & 81.35 & 106.27 & 54.81 & 1040.94 \\
\hline $10 / 31 / 2001$ & 95.30 & 67.32 & 82.82 & 104.30 & 53.36 & 1059.78 \\
\hline $11 / 30 / 2001$ & 111.45 & 79.51 & 89.04 & 121.97 & 63.02 & 1139.45 \\
\hline $12 / 31 / 2001$ & 121.52 & 83.48 & 89.72 & 132.99 & 66.17 & 1148.08 \\
\hline $1 / 31 / 2002$ & 127.05 & 88.86 & 88.32 & 139.04 & 70.43 & 1130.20 \\
\hline 2/28/2002 & 128.43 & 94.99 & 86.49 & 140.55 & 75.29 & 1106.73 \\
\hline 3/29/2002 & 141.12 & 104.16 & 89.67 & 154.44 & 82.56 & 1147.39 \\
\hline 4/30/2002 & 143.27 & 103.90 & 84.16 & 156.80 & 82.35 & 1076.92 \\
\hline
\end{tabular}




\begin{tabular}{|c|c|c|c|c|c|c|}
\hline $5 / 31 / 2002$ & 131.68 & 98.98 & 83.39 & 144.11 & 78.45 & 1067.14 \\
\hline $6 / 28 / 2002$ & 121.66 & 99.63 & 77.35 & 133.15 & 78.97 & 989.82 \\
\hline 7/31/2002 & 104.41 & 92.22 & 71.24 & 114.27 & 73.09 & 911.62 \\
\hline 8/30/2002 & 102.73 & 87.93 & 71.59 & 112.43 & 69.69 & 916.07 \\
\hline 9/30/2002 & 93.21 & 80.48 & 63.71 & 102.01 & 63.79 & 815.28 \\
\hline $10 / 31 / 2002$ & 97.03 & 75.07 & 69.22 & 106.19 & 59.50 & 885.76 \\
\hline $11 / 29 / 2002$ & 108.95 & 79.62 & 73.17 & 119.24 & 63.11 & 936.31 \\
\hline $12 / 31 / 2002$ & 102.58 & 78.75 & 68.76 & 112.26 & 62.42 & 879.82 \\
\hline $1 / 31 / 2003$ & 96.50 & 73.05 & 66.87 & 105.61 & 57.90 & 855.70 \\
\hline $2 / 28 / 2003$ & 93.11 & 62.47 & 65.73 & 101.90 & 49.51 & 841.15 \\
\hline $3 / 31 / 2003$ & 97.07 & 61.83 & 66.28 & 106.23 & 49.01 & 848.18 \\
\hline 4/30/2003 & 109.29 & 66.09 & 71.65 & 119.61 & 52.38 & 916.92 \\
\hline $5 / 30 / 2003$ & 116.64 & 75.37 & 75.30 & 127.65 & 59.74 & 963.59 \\
\hline $6 / 30 / 2003$ & 115.41 & 74.44 & 76.15 & 126.30 & 59.00 & 974.50 \\
\hline 7/31/2003 & 127.10 & 80.68 & 77.39 & 139.10 & 63.95 & 990.31 \\
\hline 8/29/2003 & 130.39 & 81.54 & 78.77 & 142.70 & 64.63 & 1008.01 \\
\hline 9/30/2003 & 134.63 & 88.77 & 77.83 & 147.34 & 70.36 & 995.97 \\
\hline $10 / 31 / 2003$ & 135.46 & 89.29 & 82.11 & 148.25 & 70.77 & 1050.71 \\
\hline $11 / 28 / 2003$ & 143.02 & 94.81 & 82.70 & 156.52 & 75.15 & 1058.20 \\
\hline $12 / 31 / 2003$ & 146.66 & 100.50 & 86.89 & 160.50 & 79.66 & 1111.92 \\
\hline 1/30/2004 & 149.37 & 103.99 & 88.39 & 163.47 & 82.42 & 1131.13 \\
\hline $2 / 27 / 2004$ & 156.49 & 102.42 & 89.47 & 171.26 & 81.18 & 1144.94 \\
\hline 3/31/2004 & 162.30 & 107.29 & 88.01 & 177.62 & 85.04 & 1126.21 \\
\hline 4/30/2004 & 166.26 & 95.90 & 86.53 & 181.95 & 76.01 & 1107.30 \\
\hline $5 / 31 / 2004$ & 167.79 & 100.37 & 87.58 & 183.63 & 79.55 & 1120.68 \\
\hline $6 / 30 / 2004$ & 179.59 & 103.38 & 89.15 & 196.54 & 81.94 & 1140.84 \\
\hline 7/30/2004 & 171.68 & 103.56 & 86.10 & 187.89 & 82.08 & 1101.72 \\
\hline $8 / 31 / 2004$ & 171.72 & 107.38 & 86.29 & 187.93 & 85.11 & 1104.24 \\
\hline 9/30/2004 & 186.92 & 109.90 & 87.10 & 204.57 & 87.11 & 1114.58 \\
\hline $10 / 29 / 2004$ & 198.81 & 113.05 & 88.32 & 217.58 & 89.60 & 1130.20 \\
\hline $11 / 30 / 2004$ & 210.45 & 120.28 & 91.73 & 230.32 & 95.33 & 1173.82 \\
\hline $12 / 31 / 2004$ & 233.40 & 130.05 & 94.71 & 255.43 & 103.08 & 1211.92 \\
\hline $1 / 31 / 2005$ & 229.71 & 121.49 & 92.31 & 251.40 & 96.29 & 1181.27 \\
\hline $2 / 28 / 2005$ & 236.49 & 119.85 & 94.06 & 258.82 & 94.99 & 1203.60 \\
\hline $3 / 31 / 2005$ & 237.02 & 119.73 & 92.26 & 259.40 & 94.90 & 1180.59 \\
\hline 4/29/2005 & 221.27 & 121.69 & 90.40 & 242.16 & 96.45 & 1156.85 \\
\hline $5 / 31 / 2005$ & 231.80 & 125.59 & 93.11 & 253.68 & 99.54 & 1191.50 \\
\hline $6 / 30 / 2005$ & 218.35 & 130.87 & 93.10 & 238.96 & 103.73 & 1191.33 \\
\hline $7 / 29 / 2005$ & 233.89 & 137.46 & 96.45 & 255.97 & 108.95 & 1234.18 \\
\hline $8 / 31 / 2005$ & 212.38 & 132.29 & 95.37 & 232.43 & 104.85 & 1220.33 \\
\hline 9/30/2005 & 207.43 & 129.52 & 96.03 & 227.01 & 102.66 & 1228.81 \\
\hline $10 / 31 / 2005$ & 196.31 & 125.71 & 94.32 & 214.84 & 99.64 & 1207.01 \\
\hline $11 / 30 / 2005$ & 220.05 & 133.03 & 97.64 & 240.82 & 105.44 & 1249.48 \\
\hline $12 / 30 / 2005$ & 222.92 & 136.21 & 97.55 & 243.96 & 107.96 & 1248.29 \\
\hline 1/31/2006 & 238.29 & 146.59 & 100.03 & 260.79 & 116.19 & 1280.08 \\
\hline 2/28/2006 & 239.84 & 146.42 & 100.08 & 262.48 & 116.05 & 1280.66 \\
\hline
\end{tabular}




$\begin{array}{ccccccc}3 / 31 / 2006 & 259.57 & 153.27 & 101.19 & 284.07 & 121.48 & 1294.83 \\ 4 / 28 / 2006 & 274.70 & 151.70 & 102.42 & 300.63 & 120.24 & 1310.61 \\ 5 / 31 / 2006 & 272.04 & 146.80 & 99.25 & 297.72 & 116.35 & 1270.09 \\ 6 / 30 / 2006 & 278.08 & 156.74 & 99.26 & 304.33 & 124.23 & 1270.20 \\ 7 / 31 / 2006 & 237.07 & 152.73 & 99.77 & 259.45 & 121.05 & 1276.66 \\ 8 / 31 / 2006 & 254.48 & 159.25 & 101.89 & 278.50 & 126.22 & 1303.82 \\ 9 / 29 / 2006 & 260.65 & 159.68 & 104.39 & 285.25 & 126.56 & 1335.85 \\ 10 / 31 / 2006 & 282.15 & 162.23 & 107.68 & 308.79 & 128.58 & 1377.94 \\ 11 / 30 / 2006 & 323.42 & 170.62 & 109.46 & 353.95 & 135.23 & 1400.63 \\ 12 / 29 / 2006 & 335.76 & 166.94 & 110.84 & 367.46 & 132.32 & 1418.30 \\ 1 / 31 / 2007 & 367.23 & 175.74 & 112.39 & 401.90 & 139.29 & 1438.24 \\ 2 / 28 / 2007 & 350.47 & 173.78 & 109.94 & 383.55 & 137.74 & 1406.82 \\ 3 / 30 / 2007 & 350.04 & 177.10 & 111.04 & 383.08 & 140.37 & 1420.86 \\ 4 / 30 / 2007 & 345.12 & 175.21 & 115.84 & 377.70 & 138.87 & 1482.37 \\ 5 / 31 / 2007 & 353.35 & 178.30 & 119.61 & 386.71 & 141.32 & 1530.62 \\ 6 / 29 / 2007 & 344.78 & 167.56 & 117.48 & 377.33 & 132.81 & 1503.35 \\ 7 / 31 / 2007 & 350.69 & 152.76 & 113.72 & 383.79 & 121.08 & 1455.27 \\ 8 / 31 / 2007 & 377.28 & 156.50 & 115.19 & 412.89 & 124.04 & 1473.99 \\ 9 / 28 / 2007 & 418.59 & 155.34 & 119.31 & 458.10 & 123.12 & 1526.75 \\ 10 / 31 / 2007 & 420.79 & 156.69 & 121.08 & 460.51 & 124.19 & 1549.38 \\ 11 / 30 / 2007 & 374.81 & 133.40 & 112.59 & 410.19 & 105.73 & 1440.70\end{array}$


VITA

Jing Yang

Candidate for the Degree of

Master of Science

Thesis: MERGER ABNORMAL RETURNS AND PAYMENT METHODS OF HOSPITALITY FIRMS

Major Field: Hospitality Administration

Biographical:

Personal Data:

Born in P.R.China, Jing Yang is the Daughter of Shicong Yang and Weixin Li.

Education:

Completed the requirements for the Master of Science in Hospitality Administration at Oklahoma State University, Stillwater, Oklahoma in May 2008. 
Institution: Oklahoma State University

Location: Stillwater, Oklahoma

Title of Study: MERGER ABNORMAL RETURNS AND PAYMENT METHODS

\section{OF HOSPITALITY FIRMS}

Pages in Study: 68

Candidate for the Degree of Master of Science

Major Field: Hospitality Administration

Scope and Method of Study: The study aims to examine the long term abnormal returns to hospitality acquirers as well as the association between excess returns and merger financing methods and size from 1996 to 2007. The study applies regression analysis with secondary data examining 19 hospitality acquirers.

Findings and Conclusions: Hospitality acquirers receive positive abnormal returns 12 months post merger and there is negative association between the cash payment and absolute size of the merger deals with the percentage excess returns. 